\title{
Levenslang leren en competentieontwikkeling
}

Citation for published version (APA):

de Grip, A., Belfi, B., Fouarge, D., Künn, A., Peeters, T., \& Poulissen, D. (2018). Levenslang leren en competentieontwikkeling: Beleidsrapport. ROA. ROA Reports No. 008

https://doi.org/10.26481/umarep.2018008

Document status and date:

Published: 01/01/2018

DOI:

10.26481/umarep.2018008

Document Version:

Publisher's PDF, also known as Version of record

\section{Please check the document version of this publication:}

- A submitted manuscript is the version of the article upon submission and before peer-review. There can be important differences between the submitted version and the official published version of record.

People interested in the research are advised to contact the author for the final version of the publication, or visit the DOI to the publisher's website.

- The final author version and the galley proof are versions of the publication after peer review.

- The final published version features the final layout of the paper including the volume, issue and page numbers.

Link to publication

\footnotetext{
General rights rights.

- You may freely distribute the URL identifying the publication in the public portal. please follow below link for the End User Agreement:

www.umlib.nl/taverne-license

Take down policy

If you believe that this document breaches copyright please contact us at:

repository@maastrichtuniversity.nl

providing details and we will investigate your claim.
}

Copyright and moral rights for the publications made accessible in the public portal are retained by the authors and/or other copyright owners and it is a condition of accessing publications that users recognise and abide by the legal requirements associated with these

- Users may download and print one copy of any publication from the public portal for the purpose of private study or research.

- You may not further distribute the material or use it for any profit-making activity or commercial gain

If the publication is distributed under the terms of Article $25 \mathrm{fa}$ of the Dutch Copyright Act, indicated by the "Taverne" license above, 


\section{Maastricht University ROA}

\section{Levenslang leren en competentie- ontwikkeling Beleidsrapport}

\section{ROA Rapport}

ROA-R-2018/8

Researchcentrum voor Onderwijs en Arbeidsmarkt | ROA Research Centre for Education and the Labour Market / ROA 


\section{LEVENSLANG LEREN EN COMPETENTIEONTWIKKELING BELEIDSRAPPORT}

ROA-R-2018/8

Andries de Grip

Barbara Belfi

Didier Fouarge

Annemarie Künn-Nelen

Tim Peeters

Davey Poulissen 


\title{
Colofon
}

(C) Researchcentrum voor Onderwijs en Arbeidsmarkt (ROA). Niets uit deze uitgave mag op enige manier worden verveelvoudigd zonder voorafgaande schriftelijke toestemming van de directeur van het ROA.

\author{
Researchcentrum voor Onderwijs en Arbeidsmarkt \\ Postbus 616 \\ 6200 MD Maastricht \\ $\mathrm{T}+31433883647$ \\ $\mathrm{F}+31433884914$ \\ secretary-roa-sbe@maastrichtuniversity.nl \\ www.roa.nl
}

School of Business and Economics

Maastricht University

\section{Vormgeving}

ROA secretariaat, Maastricht

ISBN: 978-90-5321-576-0

december 2018

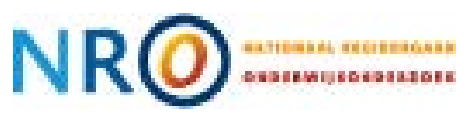

Dit rapport maakt onderdeel uit van het NRO project 'Levenslang leren en competentieontwikkeling' (dossiernummer 405-16-402). 
Voorwoord

1 Inleiding 1

2 Deelproject 1: Schoolverlaters in crisistijd 5

3 Deelproject 2: Gevraagde competencies, deelname aan scholing en informeel leren en iemands loopbaan $\quad 11$

4 Deelproject 3: Scholing en informeel leren onder kwetsbare groepen 17

5 Beleidsaanbevelingen 23

$\begin{array}{lr}\text { Literatuur } & 39\end{array}$

Bijlage 1: Programma Beleidsconferentie 'Leven lang ontwikkelen en $\begin{array}{ll}\text { competentieontwikkeling' } & 41\end{array}$

Bijlage 2: Rondetafeldiscussies Beleidsconferentie: Beleidsvragen en deelnemers 


\section{VOORWOORD}

De Nederlandse overheid ervaart het als zeer urgent een goed levenslang leren beleid te ontwikkelen dat onze kenniseconomie een impuls geeft. Daarbij staan twee aan elkaar gerelateerde vragen centraal:

- Over welke competenties moet de (vergrijzende) Nederlandse beroepsbevolking beschikken?

- Hoe kan de scholing en het informeel leren dat daarvoor nodig is worden gestimuleerd?

Het NRO project Levenslang Leren en competentieontwikkeling (405-16-402) richt zich op het beantwoorden van deze twee vragen.'

Dit rapport is het afsluitende samenvattende beleidsrapport van dit project, waarin we een overzicht geven van de belangrijkste uitkomsten van het onderzoek waarover eerder is gepubliceerd in de drie deelrapporten:

- Schoolverlaters in crisistijd: gevolgen voor leren en de vroege loopbaan, ROA-R-2018/7, Maastricht.

- Nederland in leerstand, ROA-R- 2018/4, Maastricht.

- Leren onder werkenden met een kwetsbare positie op de arbeidsmarkt, ROA-R- 2018/5, Maastricht.

In aansluiting op dit overzicht van de belangrijkste uitkomsten, gaan we in het slothoofdstuk in op een aantal beleidsaanbevelingen op basis van ons onderzoek. Daarbij maken we ook gebruik van de discussies die er gevoerd zijn op de beleidsconferentie Leven lang ontwikkelen en competentieontwikkeling, die we in samenwerking met de SER op 27 september 2018 hebben georganiseerd naar aanleiding van ons onderzoek (zie bijlage 1). Op deze conferentie hebben we de beleidsimplicaties van ons onderzoek verder uitgediept op basis van zes rondetafelgesprekken en een paneldiscussie met vertegenwoordigers van de sociale partners en de overheid.

$1 \quad$ Zie de ROA-website voor meer informatie: http://roa.sbe.maastrichtuniversity.nl/?portfolio=roa-lifelonglearning-survey 
Onze dank gaat uit naar de deelnemers aan de rondetafelgesprekken (zie bijlage 2) en de paneldiscussie: Gert-Jan Buitendijk (Ministerie SZW), Isabel Coenen (FNV), Gertrud van Erp (VNO-NCW/MKB Nederland) en Mariëtte Hamer (SER). Ook danken we Esmee Smelt voor de organisatie van de conferentie, Simone van Trier als dagvoorzitter en de notulisten van de SER voor hun verslagen van de rondetafel-discussies.

Prof. dr. Andries de Grip

Directeur ROA 


\section{INLEIDING}

Het ontwikkelen, activeren en benutten van de kennis en vaardigheden van de Nederlandse beroepsbevolking staat centraal in de Nationale Skills Strategie die momenteel door de Nederlandse regering wordt ontwikkeld in samenwerking met de SER. De uitdaging is hier groot. Door technologische en organisatorische vernieuwingen en de globalisering van de afzetmarkten in veel sectoren in de economie is er een grote dynamiek in de op de arbeidsmarkt gevraagde kennis en vaardigheden. Alleen door zich te blijven ontwikkelen blijft iemand goed inzetbaar op de arbeidsmarkt. Deze duurzame inzetbaarheid staat nog verder onder druk, omdat we op steeds latere leeftijd met pensioen gaan. Op dit punt is een aantal groepen het meest kwetsbaar: lager opgeleiden, 55-plussers en werkenden met een flexibel arbeidscontract.

Dit roept de vraag op hoe het levenslang ontwikkelen van de Nederlandse beroepsbevolking kan worden gestimuleerd. Om deze vraag te kunnen beantwoorden hebben we eerst in 3 deelprojecten gezocht naar een antwoord op de volgende vragen met betrekking tot het levenslang leren in Nederland:

1. Welke invloed heeft een recessieperiode op het leren door schoolverlaters en welke gevolgen heeft dit voor hun vroege loopbaan? (zie Belfi et al., 2018).

2. Hoe hebben de deelname aan scholing en informeel leren en de competenties van de beroepsbevolking zich de afgelopen jaren ontwikkeld in relatie tot de ontwikkeling van de op de arbeidsmarkt gevraagde competenties en wat is de invloed van de verschillende leervormen op iemands loopbaan? (zie Fouarge et al., 2018).

3. Welke aanbod- en vraagfactoren beïnvloeden de deelname aan scholing en informeel leren onder werkenden in de kwetsbare groepen: ouderen, laagopgeleiden, mensen met flexibele contracten? (zie Künn-Nelen et al., 2018). 
In deze drie deelprojecten stonden de volgende meer specifieke vragen centraal:

Deelproject 1:

Schoolverlaters in crisistijd: gevolgen voor leren en de vroege loopbaan

1a. Welke invloed heeft een recessieperiode op het leren door schoolverlaters?

1b. Welke gevolgen heeft het ontbreken van leermogelijkheden voor hun vroege loopbaan?

Deelproject 2:

Relatie tussen de gevraagde competenties, de deelname aan scholing en informeel leren en iemands loopbaan

2a. Hoe hebben de deelname aan scholing en informeel leren en de competenties van de beroepsbevolking zich de afgelopen jaren ontwikkeld in relatie tot de ontwikkeling van de op de arbeidsmarkt gevraagde competenties?

2b. Hoe effectief zijn de verschillende vormen van levenslang leren voor verschillende aspecten van iemands loopbaan?

\section{Deelproject 3:}

Determinanten van deelname aan scholing en informeel leren onder kwetsbare groepen

3a. Wat zijn de belangrijkste individuele kenmerken aan de aanbodkant van de arbeidsmarkt die het leren onder kwetsbare groepen belemmeren of bevorderen?

3b. Wat zijn de belangrijkste kenmerken aan de vraagkant van de arbeidsmarkt die het leren onder kwetsbare groepen belemmeren of bevorderen?

\section{Overzicht onderzoeksopzet}

Figuur 1.1 geeft een overzicht van het conceptuele model dat ten grondslag ligt aan het onderzoek en maakt het ook mogelijk om te laten zien hoe de drie deelprojecten samenhangen:

- Deelproject 1 richt zich op de verbanden die worden weergegeven door de oranje pijlen, met een duidelijke toespitsing op de rol van een laagconjunctuur voor het leren van schoolverlaters in de eerste jaren van hun arbeidsloopbaan.

- Deelproject 2 heeft betrekking op de hele figuur, waarbij de nadruk ligt op de ontwikkelingen in de tijd, en de relatie tussen het levenslang leren en de verdere arbeidsloopbaan.

- Deelproject 3 richt zich op de lichtblauwe kaders en hun relaties: de relatie tussen de vraag en aanbod factoren en het levenslang leren. 
In de drie volgende hoofdstukken zal een overzicht worden gegeven van de inzichten die de drie deelstudies hebben opgeleverd voor het beantwoorden van de bovenstaande vragen. Daarna zal in het slothoofdstuk worden ingegaan op de implicaties voor het HR-beleid van arbeidsorganisaties en het overheidsbeleid.

FIGUUR 1.1 Overzicht conceptueel model van het onderzoek

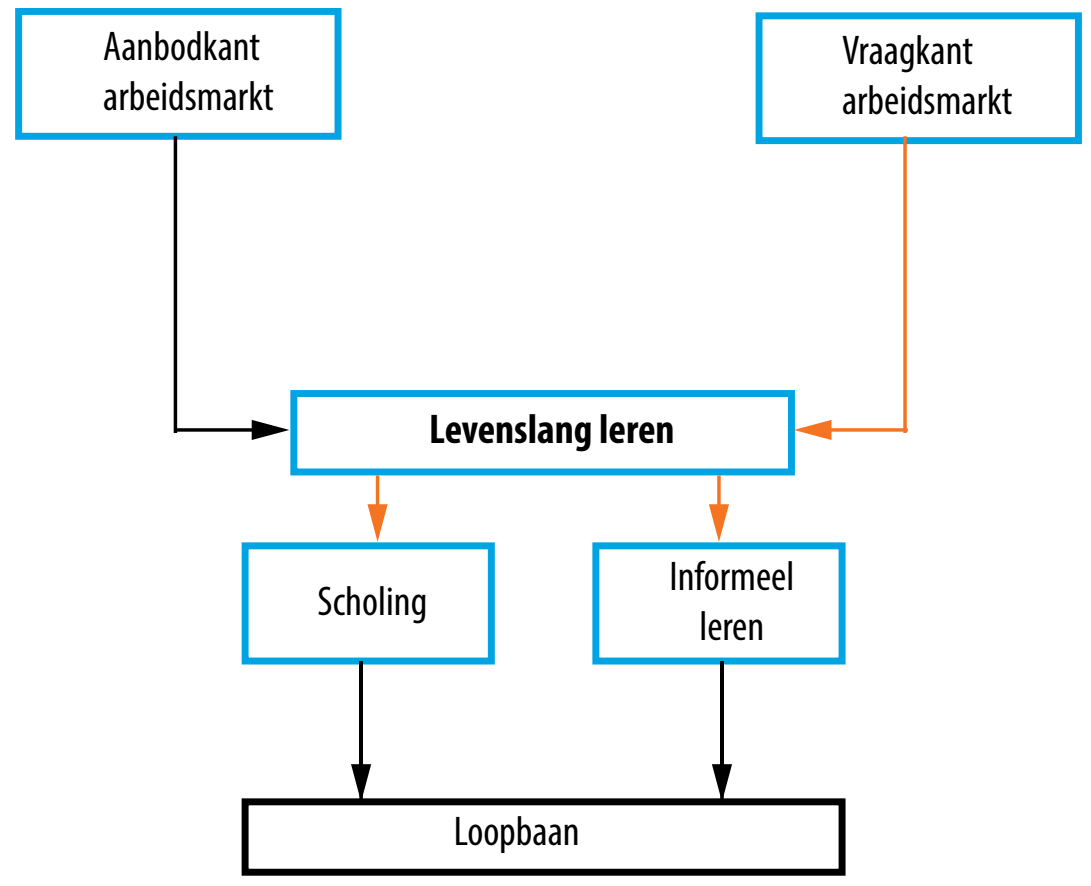





\section{DEELPROJECT 1: SCHOOLVERLATERS IN CRISISTIJD}

Het leren houdt niet op bij het afronden van het initiële onderwijs. De relatief hoge deelname aan zowel additionele scholing als informele leervormen onder jongeren die nog maar relatief kort zijn afgestudeerd laat zien dat er juist in de jaren na de school-werk transitie veel geleerd wordt (Kyndt en Baert, 2013). Voor jongeren die tijdens een economische crisis op de arbeidsmarkt instromen is het echter vaak moeilijker om een goede positie op de arbeidsmarkt te veroveren. Wat betekent dit voor de verdere leermogelijkheden van deze jongeren?

In deelproject 1 werd het verband tussen perioden van economische crisis en het leergedrag van pas afgestudeerden mbo'ers en hbo'ers onderzocht. Een verstoring van dit leergedrag kan serieuze gevolgen hebben voor de verdere loopbaan. Hiervan is vooral sprake wanneer het vroege carrièreverloop tijdens een economische recessie niet zo soepel loopt.

In deelproject 1 werd daarom onderzocht in hoeverre een recessieperiode van invloed is op het leren door schoolverlaters na het verlaten van het initiële onderwijs, en welke gevolgen eventuele belemmeringen van de leermogelijkheden hebben voor de vroege loopbaan van jongeren. Vanuit dat perspectief stonden drie vragen centraal. ${ }^{2}$ Hieronder wordt een kort overzicht gegeven van de antwoorden op deze vragen, die het onderzoek (Belfi et al., 2018) heeft kunnen geven.

- Welke invloed heeft een periode van economische crisis op het verder leren van schoolverlaters?

Tabel 2.1 geeft voor de mbo bol, mbo bbl en het hbo een overzicht van de uitkomsten van een multivariaat regressiemodel voor drie types van leergedrag:

- volgen van een vervolgstudie;

- verlenging van de studieduur (alleen voor hbo);

- deelname aan een bedrijfscursus of -training.

2 In het initiële onderzoeksvoorstel stonden twee onderzoeksvragen centraal, maar bij het uitwerken van het voorstel hebben we nog een additionele onderzoeksvraag toegevoegd. 
De tabel laat zien hoe dit leergedrag samenhangt met de conjuncturele werkloosheid op het moment dat iemand zijn of haar diploma behaalde. Daarbij is de conjuncturele werkloosheid in een bepaald jaar gedefinieerd op basis van de afwijking van het langetermijn gemiddelde werkloosheidspercentage van het desbetreffende opleidingstype. ${ }^{3}$ Uit de tabel blijkt dat een toename van het conjuncturele werkloosheidspercentage met 1 procentpunt leidt tot een toename in de kans dat mbo-bol-gediplomeerden een vervolgopleiding volgen met gemiddeld 0,3 procentpunten. Mbo-bol-gediplomeerden gaan dus vaker een vervolgopleiding volgen als de werkloosheid hoog is op het moment dat zij hun diploma behalen. Bij de hbo-gediplomeerden leidt eenzelfde conjuncturele werkloosheidstoename daarentegen voor een afname van de kans om een vervolgopleiding te volgen met 0,6 procentpunten. Hbo'ers gaan dus juist minder vaak een vervolgopleiding volgen als de werkloosheid hoog is op het moment dat zij hun diploma behalen. Wel lijkt het dat hbo'ers hun afstuderen uitstellen als de werkloosheid hoog is, bijvoorbeeld door extra vakken te gaan volgen. Zo leidt een stijging van de conjuncturele werkloosheid met 1 procentpunt tot een toename in de totale studieduur van hbo'er van 0,13 procentpunten.

Wel leidt een hogere werkloosheid op het moment van afstuderen zowel bij de mbo'ers als de hbo'ers tot een daling van de cursusdeelname. Als de werkloosheid 1 procentpunt hoger is dan daalt de cursusdeelname met ruim 1 procentpunt.

TABEL 2.1 Relatie tussen de kans op het volgen van een vervolgopleiding en conjuncturele werkloosheid in het jaar van afstuderen

\begin{tabular}{|c|c|c|c|}
\hline & Mbo bol & Mbo bbl & Hbo \\
\hline \multicolumn{4}{|c|}{ Effect conjuncturele werkloosheid in het jaar van afstuderen op: } \\
\hline - het volgen van een vervolgopleiding & $0,30^{* * *}$ & $-0,30$ & $-0,60^{* * *}$ \\
\hline - het verlengen van de studieduur & & & $0,13^{* * *}$ \\
\hline - cursusdeelname van werkenden & $-1,20^{* * *}$ & $-1,50^{* *}$ & $-1,60^{* * *}$ \\
\hline
\end{tabular}

*** $p<0.01,{ }^{* *} p<0.05$, Bron: SIS ROA, 2003-2017

Bij de mbo-analyses werd gecontroleerd voor geslacht, leeftijd, etniciteit en eindcijfer. Bij de hboanalyses werd daarnaast ook gecontroleerd voor de hoogst voltooide vooropleiding en (alleen bij het effect op het volgen van een vervolgopleiding) de bruto studieduur.

\section{- Beinvloeden economische crises de leermogelijkheden van verschillende groepen schoolverlaters op dezelfde wijze?}

Uit de Figuren 2.12 .2 blijkt dat afgestudeerden met een migratieachtergrond na afstuderen doorgaans vaker doorstromen naar vervolgonderwijs maar minder vaak aan

3 Om de interpretatie van de regressieresultaten te bevorderen, zijn de uitkomsten weergegeven in termen van marginale effecten. Bij de vervolgstudie en cursusdeelname zijn deze marginale effecten vermenigvuldigd met 100, zodat ze kunnen worden geïnterpreteerd als de procentuele wijzigingen in de kans om een vervolgopleiding of een cursus te volgen wanneer de structurele of conjuncturele werkloosheid met 1 procentpunt toeneemt. 
cursussen deelnemen dan autochtone Nederlanders. Een laagconjunctuur heeft vooral een remmend effect op het leergedrag van afgestudeerden met een migratieachtergrond. Dit remt niet alleen hun hogere doorstroom naar vervolgonderwijs, maar vergroot ook de kloof in de cursusdeelname ten opzichte van autochtone Nederlanders. Bij mbo-bbl afgestudeerden zien we echter een uitzondering op het algemeen patroon: mbo-bbl afgestudeerden met een migratieachtergrond stromen tijdens een laagconjunctuur juist vaker door naar vervolgonderwijs.

Tussen jongens en meisjes zijn er geen verschillen in de mate waarin het leergedrag samenhangt met de conjuncturele ontwikkeling. Wel blijkt dat jongens vaker een vervolgopleiding volgen en ook vaker een cursus volgen dan meisjes, maar dit geldt zowel in een hoog- als in een laagconjunctuur. Ook afgestudeerden met een hoger gemiddeld afstudeercijfer stromen vaker door naar een vervolgopleiding dan gediplomeerden met een lager gemiddeld cijfertonen, maar ook dit verschil hangt niet samen met de conjuncturele ontwikkeling.

FIGUUR 2.1 Relatie tussen etniciteit en de keuze voor een vervolgopleiding bij hoge en lage werkloosheid

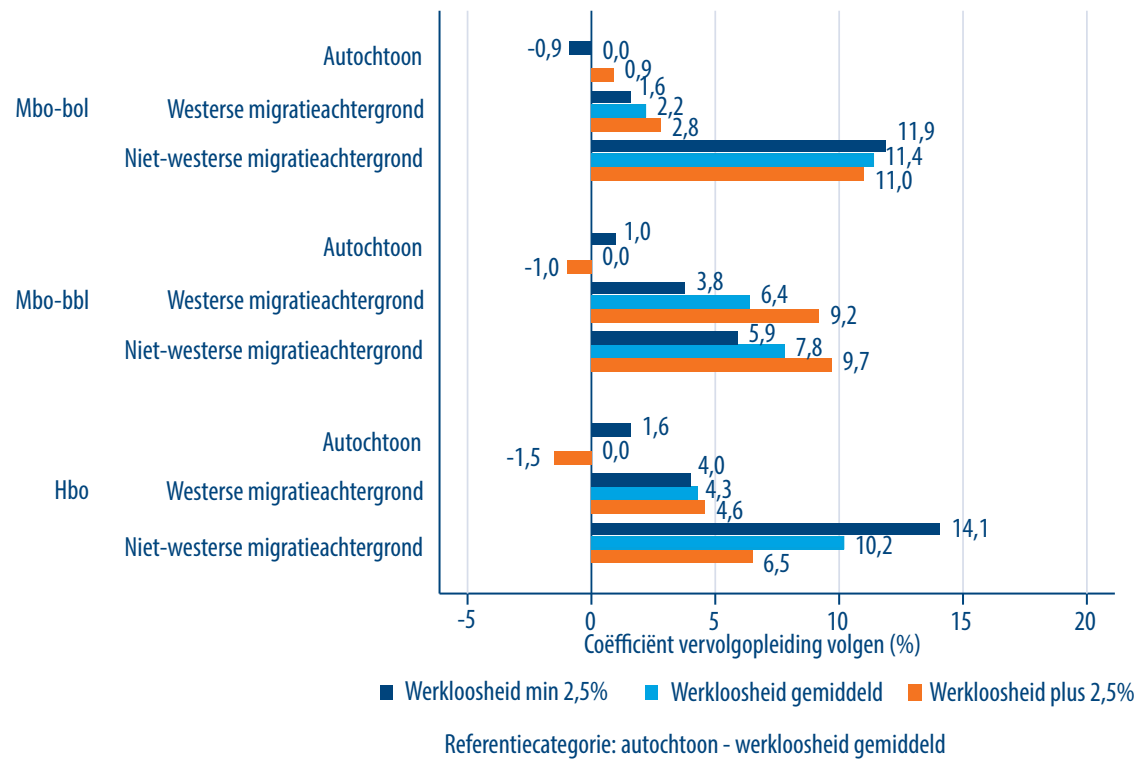


FIGUUR 2.2 Relatie tussen etniciteit en de cursusdeelname bij hoge en lage werkloosheid

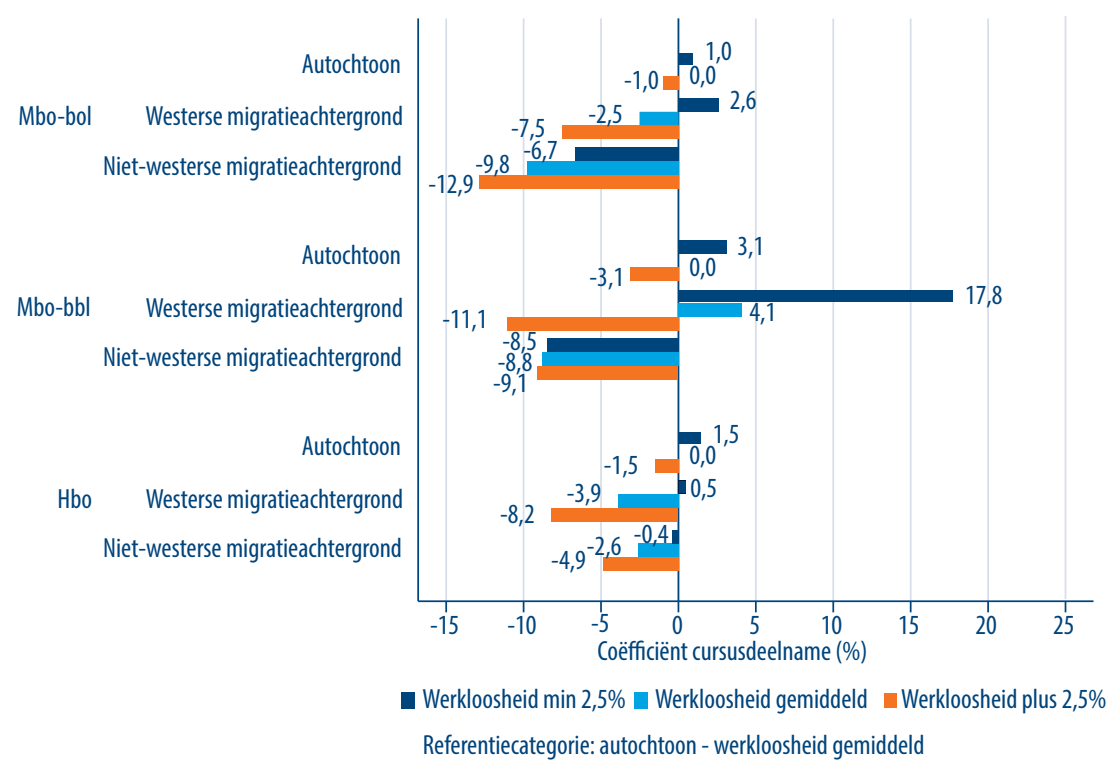

- Welke gevolgen hebben veranderingen in de leermogelijkheden tijdens een economische crisis voor de vroege loopbaan van jongeren?

Figuur 2.3 laat het model zien op basis waarvan de invloed van conjuncturele werkloosheid op de arbeidsmarktuitkomsten van mbo'ers en hbo'ers op de middellange termijn zijn onderzocht. Daarbij ligt het accent op de vraag in hoeverre deze relatie verklaard kan worden door een lagere cursusdeelname van de schoolverlaters in een laagconjunctuur. De groene pijlen geven het indirecte effect weer van de conjuncturele werkloosheid op de middellange-termijn arbeidsmarktuitkomsten dat loopt via cursusdeelname. De indirecte paden die lopen langs de arbeidsmarktuitkomsten op de korte termijn mogen niet gezien worden als een causale relatie, omdat de tijd tussen de korte-termijn leeractiviteit en arbeidsmarktuitkomst zo kort is dat we oorzaak en gevolg moeilijk van elkaar kunnen onderscheiden. 
FIGUUR 2.3 Geschatte model van de middellangetermijneffecten van laagconjunctuur op arbeidsmarktuitkomsten, in relatie tot de cursusdeelname na het verlaten van de mbo-opleiding

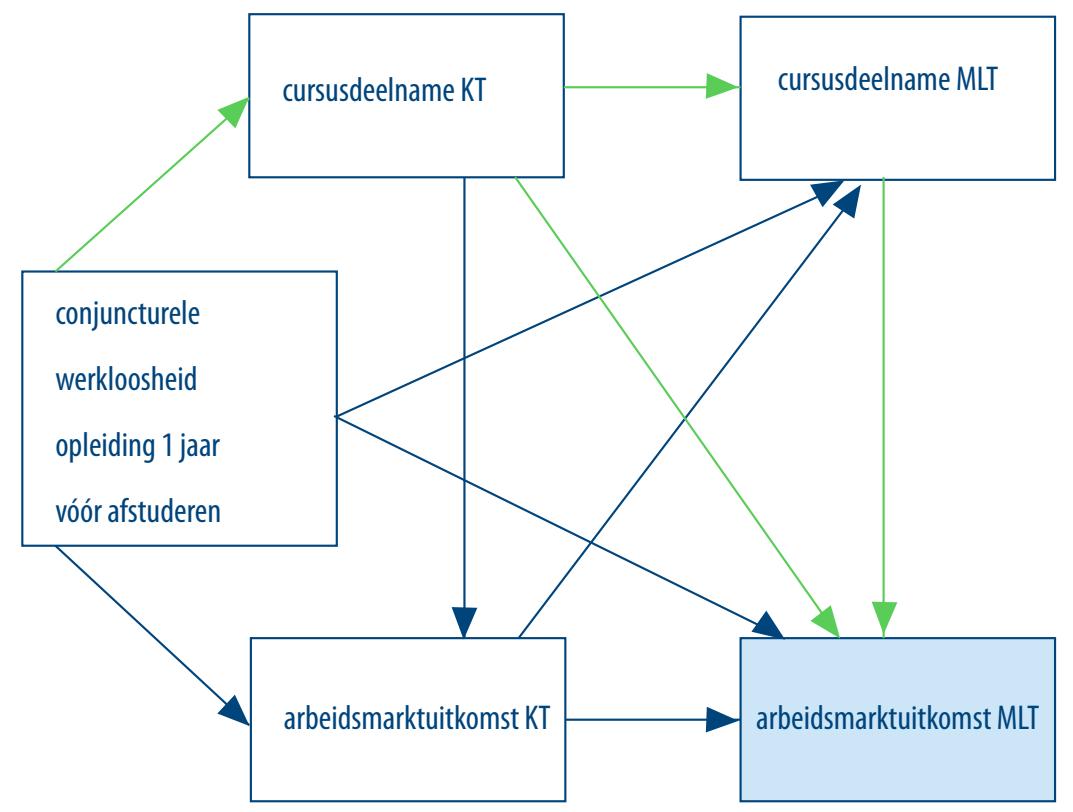

Bron: ROA

De groene paden vormen gezamenlijk het indirecte effect van conjuncturele werkloosheid op de middellange-termijn arbeidsmarktuitkomsten dat via cursusdeelname kort na het afstuderen loopt.

Bij de mbo'ers blijkt dat een laagconjunctuur niet alleen een negatieve invloed heeft op hun cursusdeelname kort na het schoolverlaten, maar ook op de cursusdeelname op de middellange termijn. De lagere cursusdeelname kort na het verlaten van een mbo-opleiding verkleint ook de kans op cursusdeelname op de middellange termijn. Ook is er een direct effect van de cursusdeelname op de korte en middellange termijn op de beloning op de middellange termijn en van de cursusdeelname op de middellange termijn op de kans op een baan in het eigen kerndomein. Hieruit blijkt dat er sprake is van verschillende wegen waarlangs een hoge conjuncturele werkloosheid op het moment van afstuderen via een lagere cursusdeelname de beloning en de kans op een baan op de middellange termijn negatief beïnvloedt. Het indirecte effect van de conjuncturele werkloosheid dat via de cursusdeelname loopt (de som van de groene pijlen in Figuur 2.3) is in zijn totaliteit voor geen enkele middellange-termijn arbeidsmarktuitkomst significant. De kleinere kans op scholing vanwege een hoge conjuncturele werkloosheid heeft dus voor mbo'ers geen waarneembare gevolgen voor hun loopbaan op middellange termijn. 
Ook de hbo'ers die tijdens een laagconjunctuur op de arbeidsmark instromen blijken op de korte termijn minder vaak een cursus te volgen. Dit verkleint ook de kans op cursusdeelname op de middellange termijn. Het indirecte negatieve effect van een hoge conjuncturele werkloosheid dat loopt via de cursusdeelname is op de middellange termijn zowel significant voor de kans op werk als de kans op een vast contract. Bij de kans op een vast contract op de middellange termijn, maakt dit indirecte effect ongeveer $15 \%$ uit van het totale effect dat de conjuncturele werkloosheid hierop heeft. Deze uitkomsten geven aan dat het dempend effect van een laagconjunctuur op de cursusdeelname grotere blijvende gevolgen heeft voor de beroepsloopbanen van hbo'ers dan voor die van mbo'ers.

Daarentegen speelt de doorstroom naar het vervolgonderwijs zowel bij de mbo'ers als de hbo'ers geen rol voor de mate waarin de conjuncturele werkloosheid bij arbeidsmarktintrede invloed heeft op de arbeidsmarktuitkomsten op de middellange termijn. 


\section{DEELPROJECT 2: GEVRAAGDE COMPETENCIES, DEELNAME AAN SCHOLING EN INFORMEEL LEREN EN IEMANDS LOOPBAAN}

Het doel van levenslang leren is het op peil houden en verhogen van competenties zodat men inzetbaar blijft op de arbeidsmarkt. Echter, de vraag naar competenties is veranderlijk (Bijlsma et al., 2015). Daarnaast kunnen niet alle competenties op eenzelfde manier verworven worden (van den Berg et al., 2018) en de deelname aan cursussen of training is lang niet de enige manier om competenties te leren. Werkenden leren immers ook veel door te doen. Vanuit dat perspectief stonden in deelproject 2 twee vragen centraal. Hieronder wordt een kort overzicht gegeven van de antwoorden op deze vragen, die het onderzoek (Fouarge et al., 2018) heeft kunnen geven.

- Hoe hebben de deelname aan scholing en informeel leren en de competenties van de beroepsbevolking zich de afgelopen jaren ontwikkeld in relatie tot de ontwikkeling van de op de arbeidsmarkt gevraagde competenties?

\section{Ontwikkelingen in de tijd}

Figuur 3.1 laat zien wat de ontwikkeling is geweest in de cursusdeelname in de periode 2004-2017. Daarbij wordt een onderscheid gemaakt tussen werkenden en nietwerkenden (exclusief studenten). De figuur laat zien dat er in de afgelopen 13 jaar weinig veranderingen hebben plaatsgevonden in de cursusdeelname. In 2017 gaf ruim de helft (54\%) van de werkenden aan in de afgelopen twee jaar een training of cursus te hebben gevolgd, en dat percentage is vergelijkbaar met dat in eerdere jaren. Ruim driekwart van de cursussen leidt tot een diploma of certificaat. Van de werkenden gaf 37 procent aan dat zij zelf het initiatief hadden genomen voor het volgen van de cursus, terwijl bij 35 procent de werkgever de initiatiefnemer was en het volgen van de cursus bij 26 procent van de werkenden het gezamenlijke initiatief was van werknemer en werkgever. Ruim de helft van de cursussen (55\%) was gericht op vaktechnische kennis en vaardigheden. Daarnaast waren de cursussen relatief vaak gericht op communicatie- en presentatievaardigheden (8\%) en persoonlijke ontwikkeling (8\%).

Hoewel de cursusdeelname stabiel is, groeit de kloof tussen laag- en hoogopgeleiden en daalt, mede door pensioenhervormingen, de kloof tussen jong en oud. In het kader van de toenemende dynamiek op de arbeidsmarkt is het bovendien zorgelijk dat ruim één kwart van de werkenden nog nooit een cursus heeft gevolgd. Dit roept de vraag op in welke mate deze groep werkenden in staat is om veranderingen in de op de arbeids- 
markt gevraagde vaardigheden bij te houden. In Künn-Nelen et al. (2018) wordt ingegaan op de factoren die de cursusdeelname stimuleren of belemmeren. Hieruit blijkt dat werknemers vaker bereid zijn een cursus te volgen als deze gericht is op vaktechnische kennis en vaardigheden en er geen eigen bijdrage in termen van geld en vrije tijd nodig is.

FIGUUR 3.1 Formeel leren: ontwikkeling van de deelname aan cursussen en trainingen, 2004-2017

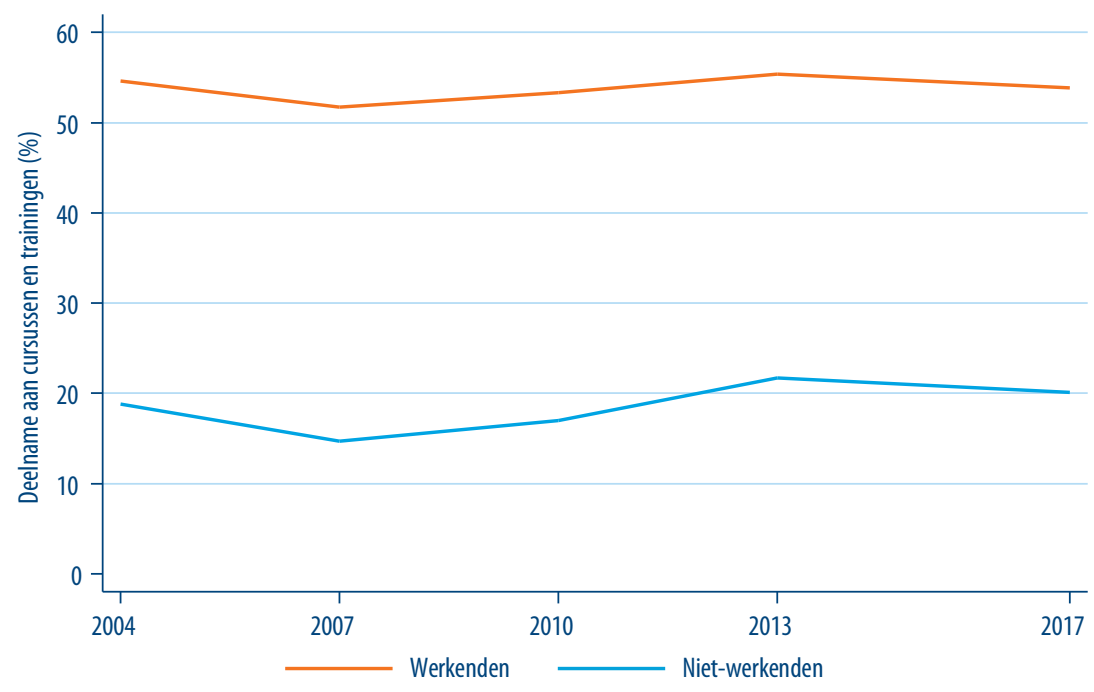

Bron: ROA LLL enquête, 2004-2017

Werkenden besteden veel tijd aan leerzame activiteiten op het werk: $24 \%$ van hun werktijd. Het informele leren lijkt wel af te nemen tussen 2004 en 2017 (Figuur 3.2), mogelijk als gevolg van een toenemende specialisatie in het werk. Desalniettemin blijft de tijd die besteed wordt aan leerzame taken een belangrijke plaats innemen in de totale tijd waarin iemand leert: gemiddeld heeft slechts 15 procent van iemands totale leertijd op het werk betrekking op het leren van cursussen, terwijl $85 \%$ van het leren het gevolg is van informele leeractiviteiten. In kleine bedrijven ligt de cursusdeelname lager dan in grote bedrijven. Echter, het informeel leren van de taken op het werk is niet afhankelijk van de grootte van het bedrijf. Dit betekent dat de taken van werkenden in kleine bedrijven even leerzaam zijn als de taken van werkenden in grote bedrijven.

Werkenden kunnen ook leren van hun activiteiten buiten het werk, zoals bij het doen van vrijwilligerswerk, of het verlenen van mantelzorg. Uit Figuur 3.3 blijkt dat als de leeractiviteiten buiten het werk worden meegenomen, het informeel leren van de taken op het werk nog steeds het overgrote deel van de totale leertijd uitmaakt (67\%) en de cursussen die men volgt slechts 12 procent. Dat betekent dat 21\% van de leertijd betrekking heeft op het informele leren van verschillende activiteiten buiten het werk. Het belangrijkst daarbij is de tijd met kinderen ( $14 \%$ van de totale leertijd). Het aandeel van 
zelfstudie ligt met 5 procent van de totale leertijd lager. Ten slotte zien we dat zowel vrijwilligerswerk als mantelzorg slechts 1 procent van de totale leertijd in beslag nemen. Wat men leert tijdens vrijwilligerswerk, mantelzorg en de tijd met kinderen is volgens de respondenten zelf overigens lang niet altijd direct bruikbaar op het werk.

FIGUUR 3.2 Informeel leren op het werk: ontwikkeling van het percentage van de werktijd besteed aan activiteiten waarvan men kan leren, 2004-2017

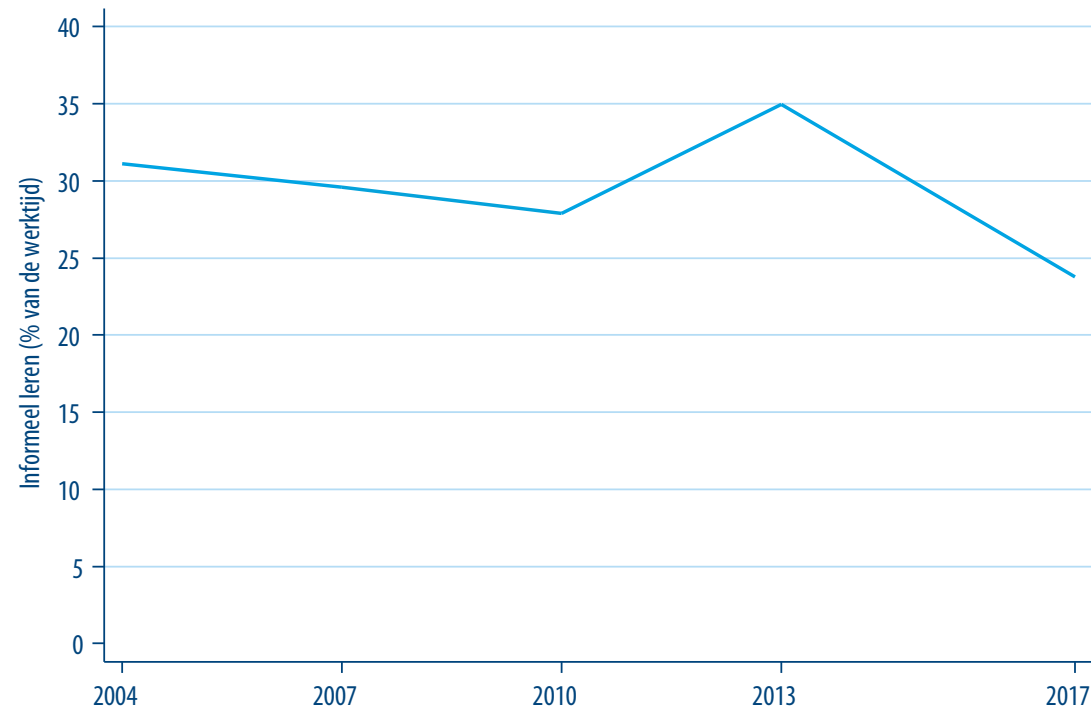

Bron: ROA LLL enquête, 2004-2017

FIGUUR 3.3 Totale leertijd van werkenden, onderverdeeld voor een gemiddeld persoon, 2017

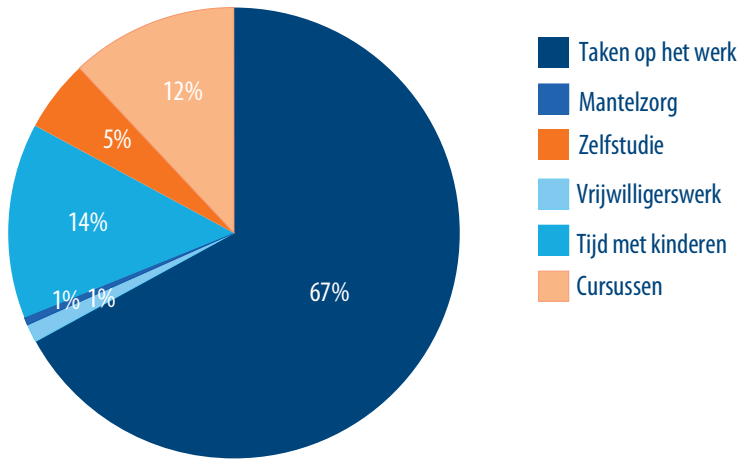

Bron: ROA LLL enquête, 2004-2017 
Door cursussen die werkenden volgen en de taken die ze hebben op het werk kunnen zij hun kennis en vaardigheden verder ontwikkelen. Werkenden geven aan dat het niveau van hun kennis en vaardigheden in de afgelopen 2 jaar 9 procentpunt dichter in de buurt is gekomen van het niveau dat nodig is om optimaal in hun functie te functioneren. Deze kennisontwikkeling ligt hoger dan in de voorgaande jaren (Figuur 3.4).

FIGUUR 3.4 Kennisontwikkeling: ontwikkeling van de toename van kennis en vaardigheden van werkenden in de afgelopen twee jaar, 2004-2017

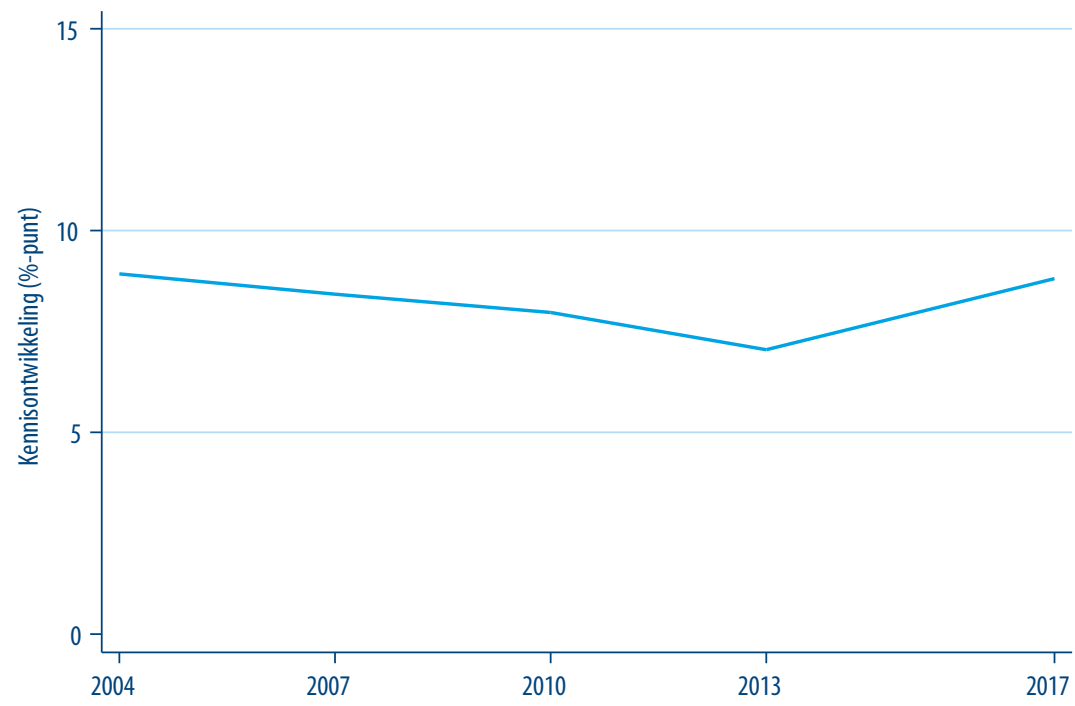

Bron: ROA LLL enquête, 2004-2017

\section{Leren en taken op het werk}

lemands leergedrag en kennisontwikkeling ligt doorgaans op een hoger niveau als interpersoonlijke vaardigheden, taalvaardigheden en probleemoplossend vermogen belangrijk zijn voor het werk. Dit geldt zowel voor de cursusdeelname als voor het informele leren op het werk. Werkenden die te maken hebben met grote technologische of organisatorische ontwikkelingen volgen ook vaker een cursus en leren ook significant meer van hun werkzaamheden.

De relatie tussen de taken die iemand op het werk heeft en zijn of haar kennisontwikkeling is echter niet eenvoudig vast te stellen. Ten eerste vinden wij geen significant verband tussen de taken die iemand nu uitoefent en iemands kennisontwikkeling in de afgelopen twee jaar. Wel is het zo dat iemands kennisontwikkeling groter is als hij of zij in het verleden taken heeft uitgevoerd waarvoor taalvaardigheden of plannen en organiseren belangrijk waren. Wanneer op het werk het gebruik van computers belangrijk was, dan is de kennisontwikkeling in de jaren daarna echter lager. Ten tweede laten wij in onderzoek op basis van de Nederlandse Skills Survey zien dat, zowel de cursusdeelname 
als het informeel leren positief samenhangen met de taakeffectiviteit van werkenden (Van den Berg et al., 2018). Echter, in een analyse waarin gecontroleerd wordt voor endogene selectie leidt vooral het informeel leren tot een verbeterde taakeffectiviteit. Werkenden geven aan dat zij behoorlijk effectief zijn in het uitvoeren van hun werktaken (Van den Berg et al., 2018). Dit suggereert dat de match tussen taakeisen en taakeffectiviteit goed is en dat mensen vaak meer kunnen dan van hen wordt gevraagd.

\section{- Hoe effectief zijn de verschillende vormen van levenslang leren voor verschil- lende aspecten van iemands loopbaan?}

Automatisering biedt kansen voor nieuw werkgelegenheid, maar wordt ook gezien als een bedreiging voor een deel van de werkgelegenheid (Van den Berge \& Ter Weel, 2015). Het risico op baanverlies wordt hoger ingeschat als iemand werkzaam is in een beroep met een groter automatiseringsrisico. Bij grote organisatorische ontwikkelingen op het werk en een sterke instabiliteit op de markt hebben werkenden een negatiever beeld van hun externe employability. ${ }^{4}$ Technologische ontwikkelingen op het werk verlagen het geschatte risico op baanverlies terwijl organisatorische ontwikkelingen deze juist verhogen. Degenen die werkzaam zijn in een organisatie die actief is op een meer onzekere afzetmarkt schatten het risico op baanverlies ook hoger in. Automatisering, technologische en organisatorische veranderingen die bedrijven meemaken kunnen door beleid echter moeilijk worden aangestuurd.

Ook baanveranderingen zorgen voor een grotere kennisontwikkeling. Dit suggereert dat het veranderen van werktaken werkenden stimuleert om nieuwe kennis op te doen. In Van den Berg et al. (2018) laten wij zien dat veranderingen van beroep gepaard gaan met een toenemend belang van rekenvaardigheden, probleemoplossend vermogen, en computervaardigheden, al zijn deze verbanden niet precies te schatten. We vinden echter geen statistisch significant verband tussen veranderingen van baan of beroep en de effectiviteit waarmee de taken worden uitgevoerd. Dat geeft aan dat productiviteitsverliezen bij baanwisselingen gering zijn en dat de meeste baanwisselingen waarschijnlijk vrijwillig zijn.

Werkenden die een cursus hebben gevolgd, hebben een positiever beeld van hun eigen externe employability en denken minder risico te lopen op baanverlies. Het veel informeel leren op het werk speelt geen rol voor iemands externe employability en kans op baanverlies als er gecontroleerd wordt voor achtergrondkenmerken. Ook het informeel leren buiten het werk, in de vorm van vrijwilligerswerk, mantelzorg, tijd met kinderen of zelfstudie heeft geen relatie met iemands externe employability.

Ongeacht welke cursus iemand gevolgd heeft, wordt het risico op baanverlies lager ingeschat dan door werkenden die geen cursus hebben gevolgd. De enige uitzondering is een cursus die alleen relevant is voor een loopbaan buiten het bedrijf; dan is

4 Onder externe employability verstaan wij de kans dat als iemand nu op zoek zou moeten naar een andere baan, hij of zij een baan zou kunnen krijgen op een vergelijkbaar niveau als de huidige baan. 
het gepercipieerde risico op baanverlies wel hoger. Een mogelijke verklaring hiervoor is dat iemand die een cursus volgt die alleen bedoeld is om de externe employability te verhogen, reeds anticipeert op het dreigende verlies van de huidige baan.

In Van Eldert et al. (2018) laten wij zien dat cursussen gericht op het verbeteren van het probleemoplossend vermogen samenhangen met een hogere kans op een vergelijkbare baan, terwijl vooral cursussen gericht op vakspecifieke kennis samenhangen met een klein gepercipieerd risico op baanverlies. Cursussen gericht op samenwerken, vakspecifieke kennis en leiding geven gaan gepaard met een hoger loon. Daarnaast lijken cursussen die zowel gericht zijn op een loopbaan binnen als buiten de huidige organisatie, nuttig voor de inzetbaarheid en het loon. Tot slot laten Van Eldert et al. (2018) zien dat het volgen van een cursus alleen niet afdoende is. Alleen wanneer de getrainde kennis en vaardigheden daadwerkelijk in de praktijk toegepast worden, gaat het volgen van cursussen gepaard met een betere inzetbaarheid en een hoger loon.

Werkenden die een cursus hebben gevolgd verwachten een halfjaar later met pensioen te gaan dan werkenden die geen cursus hebben gevolgd. De hogere verwachte pensioenleeftijd wordt gedreven door cursussen die gericht zijn op vaktechnische kennis en vermogen of digitale vaardigheden en zowel binnen als buiten het bedrijf bruikbaar zijn. 


\section{DEELPROJECT 3: SCHOLING EN INFORMEEL LEREN ONDER KWETSBARE GROEPEN}

Het doel van levenslang leren is het op peil houden en verhogen van competenties zodat iedereen inzetbaar blijft op de arbeidsmarkt. Verschillende groepen werkenden hebben echter een zwakkere positie op de arbeidsmarkt. Dit als gevolg van of versterkt door een aantal belangrijke maatschappelijke ontwikkelingen en trends. Zo vergrijst de beroepsbevolking, is er sprake van upgrading van de werkgelegenheidsstructuur en flexibiliseert de arbeidsmarkt in hoog tempo. Deze ontwikkelingen maakt de duurzame inzetbaarheid van 55-66-jarigen, laagopgeleiden en werknemers met een tijdelijk dienstverband kwetsbaar. Daarom is het erg belangrijk dat deze mensen hun competenties up-to-date houden door te blijven leren. Vanuit dit perspectief stonden in deelproject 3 twee vragen centraal. Hieronder wordt allereerst kort ingegaan op het werkgerelateerd leren van deze groepen werkenden. We laten zien of en in hoeverre zij achterlopen op andere werkenden, en we vatten de belangrijkste determinanten van het werkgerelateerd leren voor deze groepen samen. Daarna wordt een kort overzicht gegeven van de antwoorden op de twee deelvragen die het onderzoek (Künn-Nelen et al., 2018) heeft kunnen geven. 
FIGUUR 4.1 Cursusdeelname naar type werkenden (\%)

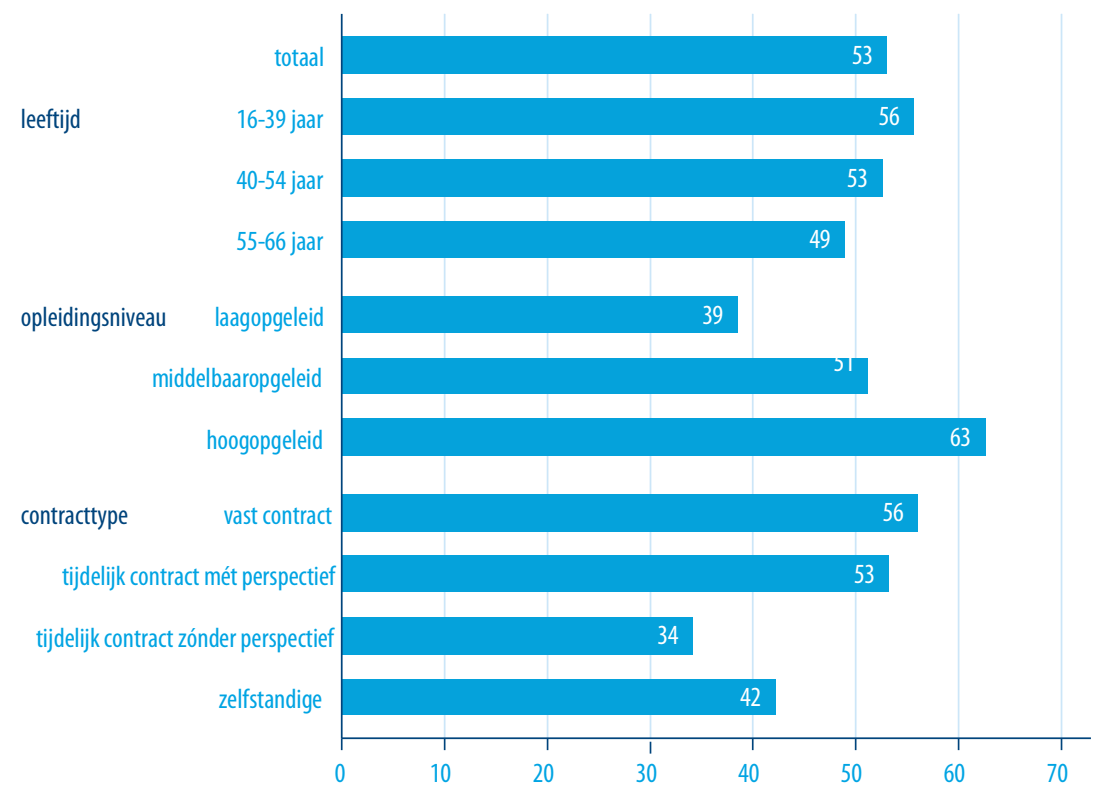

Bron: ROA LLL Enquête, 2017

Uit Figuur 4.1 blijkt dat minder dan de helft van de werkenden met een kwetsbare positie op de arbeidsmarkt (d.w.z. behorend tot de groep 55-66-jarigen, laagopgeleiden of werkenden met een tijdelijk arbeidscontract) in de afgelopen twee jaar een werkgerelateerde cursus gevolgd heeft. De referentiegroepen met een sterkere arbeidsmarktpositie participeren beduidend vaker in een cursus of training. Terwijl het verschil in scholingsdeelname tussen 55-plussers en jongere werkenden volledig te wijten blijkt aan verschillen in opleidingsachtergrond, het aantal uren dat men werkzaam is en het type dienstverband tussen werkenden in verschillende leeftijdscategorieën, geldt voor het verschil in scholingsdeelname tussen laag- en hoogopgeleiden dat dit voor 50\% verklaard kan worden door een andere werkinhoud (met name een ander takenpakket).

Werkenden leren niet enkel van cursussen, maar ook van de taken die zij uitoefenen (Arrow, 1962). In Figuur 4.2 is voor de verschillende groepen werkenden weergegeven hoeveel procent van hun werktijd zij besteden aan taken waarvan ze kunnen leren (informeel leren). Uit de figuur blijkt dat 55-plussers en laagopgeleiden relatief weinig werktijd besteden aan taken waarvan ze kunnen leren. Echter, het verschil tussen het informeel leren tussen laag- en hoogopgeleiden blijkt na een correctie voor verschil in leeftijd, contractvorm, persoonlijkheid en door verschillen in de inhoud van het werk tussen deze groepen te verdwijnen. Werknemers met een tijdelijk arbeidscontract 
blijken juist relatief veel informeel te leren op het werk. Dit blijkt slechts gedeeltelijk het gevolg van minder ervaring.

FIGUUR 4.2 Informeel leren op het werk in procenten van de werktijd naar type werkenden (\%)

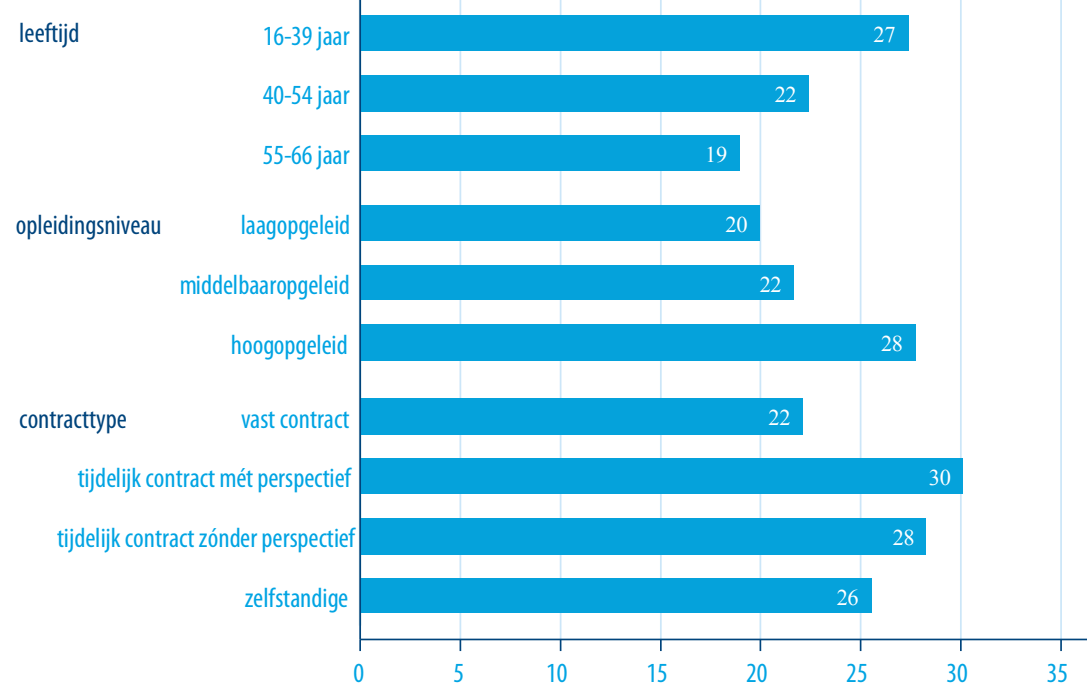

Bron: ROA LLL Enquête, 2017

- Wat zijn de belangrijkste individuele kenmerken aan de aanbodkant van de arbeidsmarkt die het leren onder kwetsbare groepen belemmeren of bevorderen?

Op basis van een vignetonderzoek hebben we in kaart gebracht welke factoren bepalend zijn voor de cursuskeuze van werknemers. Werknemers zijn een drietal keer gevraagd hun voorkeur voor een cursus aan te geven waarbij telkens twee cursussen werden getoond. Deze cursussen verschilden op de volgende gebieden: getrainde vaardigheden (vaktechnische kennis en vaardigheden, sociale en communicatieve vaardigheden, loopbaanoriëntatie en coaching), de loopbaan waar de cursus op gericht was (huidige baan, loopbaan binnen de huidige organisatie, loopbaan buiten de huidige organisatie), eigen bijdrage (o euro, 100 euro, 200 euro), cursuslast (8 uur onder werktijd, 4 uur onder werktijd en 4 uur in eigen tijd, 8 uur in eigen tijd), beoordeling (geen eindtoets/beoordeling, beoordeling op basis van persoonlijke inzet tijdens cursus, eindtoets op basis van opgedane kennis en vaardigheden) en cursusvorm (klassikale lessen, individuele training, online cursus).

We vinden weinig verschillen in de stimulerende en belemmerende factoren voor de cursuskeuze tussen werknemers met een zwakke positie op de arbeidsmarkt en werkne- 
mers met een goede positie. Mensen kiezen een cursus significant minder vaak als deze betrekking heeft op sociale en communicatieve vaardigheden, of als deze ingaat op loopbaanoriëntatie en coaching, dan een cursus die gericht is op vaktechnische kennis en vaardigheden. Het maakt voor werkenden niet uit of de cursus zich richt op de huidige baan of een loopbaan binnen of buiten de huidige organisatie. Daarentegen blijkt de mate waarin respondenten een eigen bijdrage in termen van geld of tijd moeten leveren wel degelijk van belang. Een eigen financiële bijdrage van 100 euro verkleint de kans om de cursus te kiezen met ongeveer 2 procentpunt, een eigen bijdrage van 200 euro zelfs met 5 procentpunt. Een cursus die gedeeltelijk in eigen tijd moet worden gevolgd, wordt niet significant minder vaak gekozen dan een cursus die geheel tijdens werktijd kan worden gevolgd. Echter, wanneer een cursus geheel in eigen tijd moet worden gevolgd dan verkleint dit de kans om de cursus gekozen wordt met 2 procentpunt ten opzichte van een cursus die men geheel in werktijd kan volgen. De manier waarop de in de cursus opgedane kennis en vaardigheden al dan niet getoetst worden blijkt voor werkenden niet van belang te zijn. Ten slotte blijkt dat men minder graag een online cursus volgt dan klassikale lessen of een individuele training.

Deze bevindingen gelden voor alle soorten werknemers. Er zijn slechts twee uitzonderingen: werknemers met een tijdelijk contract zonder uitzicht op een vaste aanstelling schrikken niet af van een eigen financiële bijdrage of van het volgen van cursus in eigen tijd. Ook geldt voor deze groep werknemers dat zij, in tegenstelling tot andere werknemers, niet minder maar juist meer bereid zijn om een cursus te volgen gericht op loopbaanoriëntatie en coaching.

Onze analyses laten verder zien dat iemands persoonlijkheid de cursuskeuze beïnvloedt. Zo blijken werknemers met een hoge mate van vertrouwen meer bereid zijn om een cursus te kiezen als hier een eigen bijdrage aan verbonden is dan werknemers met een laag niveau van vertrouwen in anderen. Daarnaast blijkt de belemmerende rol die een eigen bijdrage in termen van tijd speelt in de cursusdeelname kleiner te zijn voor mensen die meer bereid zijn risico's te nemen en voor mensen met een lagere tijdsvoorkeur.

Verder blijkt uit onze analyses dat werknemers met thuiswonende kinderen zijn minder bereid een cursus in eigen tijd te volgen dan werknemers zonder thuiswonende kinderen.

Hoewel de meeste stimulerende en belemmerende factoren voor cursuskeuze hetzelfde zijn voor alle soorten werkenden, geldt wel dat de mate waarin deze factoren het voornemen om een cursus daadwerkelijk te volgen verschilt. Hoewel laagopgeleiden en 55-plussers een cursus op eenzelfde manier kiezen als andere werknemers, hebben zij een beduidend lagere bereidheid daadwerkelijk een cursus te gaan volgen. Dit resultaat laat zien dat de lagere trainingsdeelname van laagopgeleiden en 55-plussers met name het gevolg is van hun lagere bereidheid om een training te volgen. 
- Wat zijn de belangrijkste kenmerken aan de vraagkant van de arbeidsmarkt die het leren onder kwetsbare groepen belemmeren of bevorderen?

Onder alle groepen met een kwetsbare positie op de arbeidsmarkt verklaart het door de werkgever gevoerde HR-beleid onder laagopgeleiden het grootste deel van de variantie in het formele en informele leren. Met name feedback van collega's en het hebben van een opleidings- of ontwikkelplan spelen een positieve rol. Het ontvangen van feedback van de leidinggevende is daarentegen negatief gerelateerd aan scholingsdeelname van laagopgeleiden.

Het HR-beleid blijkt een beduidend kleinere rol te hebben in het verklaren van het trainingsgedrag van 55-plussers dan onder werkenden van andere leeftijdsgroepen. Bij oudere werkenden is vooral taakroulatie en coaching positief gerelateerd aan cursusdeelname. Een persoonlijk opleidings- of ontwikkelplan is daarentegen niet gerelateerd aan cursusdeelname van 55-plussers terwijl dit voor jongere werknemers wel het geval is.

Op basis van een vignetonderzoek hebben we de werkgeversbereidheid om cursussen aan te bieden aan werknemers met een kwetsbare positie op de arbeidsmarkt in kaart gebracht. Van alle onderzochte groepen met een kwetsbare positie op de arbeidsmarkt blijken werkgevers het minst bereid om in de scholing van tijdelijke werknemers te investeren. Ook blijken werkgevers minder bereid om in 60-jarigen te investeren, maar maken ze geen onderscheid tussen laag- en hoogopgeleiden.

Een 60-jarige werknemer heeft nog minder kans om scholing aangeboden te krijgen als hij/zij in deeltijd werkt. Deze zogenaamde deeltijdpenalty vinden we overigens ook voor 30 en 45-jarige werknemers. Een goede performance en een goede werkmotivatie kunnen de lagere kans op scholingsaanbod van 60-jarigen deels compenseren. lemands motivatie speelt daarbij een belangrijkere rol dan iemands performance. Echter, aanvullende analyses laten zien dat werkgevers de gemiddelde leermotivatie en het gemiddelde leervermogen van hun werknemers lager inschatten naarmate werknemers ouder zijn. Deze percepties vormen daarom een gedeeltelijke verklaring voor de lagere werkgeversbereidheid om aan 60-jarigen scholing aan te bieden.

Werkgevers hebben geen grote voorkeur in het aanbieden van training aan werknemers met een bepaald opleidingsniveau, gegeven dat andere kenmerken van de werknemers gelijk zijn. Werkgevers zijn daarentegen het meeste bereid om scholing aan te bieden aan werknemers die bereid zijn een eigen bijdrage in termen van tijd en geld te leveren. Ook bieden zij het liefst een cursus gericht op vaktechnische kennis aan en hebben ze een kleine voorkeur voor het aanbieden van cursussen die uitsluitend in hun eigen organisatie bruikbaar zijn.

Werkgevers blijken minder bereid om scholing aan te bieden aan werknemers met een tijdelijk contract. Werknemers met een tijdelijk contract zonder uitzicht op een vaste 
aanstelling hebben maar liefst 37 procentpunt minder kans een cursus aangeboden te krijgen dan werknemers met een vast contract. Een terugbetalingsverplichting van de gemaakte scholingskosten bij vroegtijdig vertrek en een eigen financiële bijdrage vanuit de werknemer verhogen de kans dat werkgevers scholing aanbieden. Echter, tijdelijke werknemers zonder uitzicht op vast werk hebben zelfs bij een hoge eigen bijdrage een veel lagere scholingskans dan tijdelijke werknemers met uitzicht op vast of vaste medewerkers. Als werknemers met een tijdelijk contract met uitzicht op een vaste aanstelling gebonden zijn aan een terugbetalingsverplichting van $50 \%$ van de scholingskosten bij vroegtijdig vertrek hebben zijn een vergelijkbare scholingskans als vaste medewerkers zonder terugbetalingsverplichting. 


\section{BELEIDSAANBEVELINGEN}

De aandacht die er momenteel uitgaat naar het belang van levenslang leren benadrukt dat het leren van de kennis en vaardigheden die nodig zijn om goed te kunnen functioneren op de arbeidsmarkt zich niet beperkt tot het initiële onderwijs. Blijven leren en ontwikkelen is gedurende de hele loopbaan van belang. Hieronder volgen een reeks beleidsaanbevelingen gebaseerd op de resultaten van de drie deelprojecten.

\section{Schoolverlaters in crisistijd}

\section{Nazorg voor alumni}

Mbo-en hbo-scholen zouden een centrale rol kunnen spelen bij het up-to-date houden van de competenties van hun alumni ten opzichte van de ontwikkelingen van de vraag vanuit de arbeidsmarkt. Om dit te kunnen realiseren is het belangrijk dat onderwijsinstellingen een systematisch alumnibeleid opzetten. In dit alumnibeleid zou het aanbieden van post-initiële scholing aan afgestudeerden centraal moeten staan. Voor onderwijsinstellingen betekent dit dat er additionele inkomstenbronnen dienen te worden aangeboord, maar ook dat de de gebouwen van onderwijsinstellingen efficiënter kunnen worden benut. Door het aanbieden van post-initiële scholing aan afgestudeerden zou de leegstand van onderwijsgebouwen buiten de normale onderwijstijden immers kunnen afnemen. Voor de alumni resulteert dit in een breder scholingsaanbod dat goed gerelateerd is aan de gevolgde initiële opleidingen.

Er zou in het alumnibeleid van onderwijsinstellingen speciale aandacht moeten komen voor werkloze alumni en alumni die zijn afgestudeerd in crisistijd. Werkloze schoolverlaters volgen volgens ons onderzoek immers minder vaak een cursus of training dan werkende schoolverlaters. Ook blijkt uit ons onderzoek dat werkende schoolverlaters die tijdens een laagconjunctuur afstuderen minder vaak een cursus of training volgen dan schoolverlater die in een hoogconjunctuur op de arbeidsmarkt instromen. Werklozen en afgestudeerden in crisistijd bouwen daardoor waarschijnlijk een achterstand op in het up-to-date houden van hun competenties. Omdat werklozen en afgestudeerden in crisistijd vaak ook minder draagkrachtig zijn dan werkenden en degenen die in hoogconjunctuur afstuderen, en omdat werklozen per definitie geen werkgever hebben die (een gedeelte van) de scholingskosten zou kunnen dragen, is de vraag naar scholing onder deze groepen wellicht ook lager. Voor onderwijsinstellingen betekent dit dat het 
moeilijker zal zijn om voor deze groepen een vorm van post-initieel onderwijs aan te bieden die bekostigd kan worden. Wellicht kan de overheid hier, eventueel in samenspraak met de sociale partners, het UWV en sectorfondsen, een rol spelen door een deel van de financiering op zich te nemen of door een nog te ontwikkelen individuele leerrekening (zie hieronder) deels op deze groepen te focussen.

Een andere manier waarop onderwijsinstellingen op een flexibele manier met periodes van laagconjunctuur zouden kunnen omgaan is door schoolverlaters direct na hun diplomering specifieke modules aan te bieden die hen nog specifieker voorbereiden op de competenties die op de arbeidsmarkt van hen gevraagd worden. Daarbij zou ook ingegaan kunnen worden op de mogelijkheden tot zelfstandig ondernemerschap in het vakgebied. Door deze modules los te koppelen van het al dan niet behalen van het diploma, wordt aan elke schoolverlater de keuze gelaten of hij of zij denkt hierdoor hun arbeidsmarktintrede en toekomstige arbeidsmarktperspectieven te kunnen verbeteren. Een succesvolle afronding van deze modules zou kunnen leiden tot certificaten, waarmee schoolverlaters hun additionele competenties aan potentiële werkgevers kunnen aantonen.

\section{Lagere studiekosten in crisisperioden}

Een mogelijkheid om de arbeidsmarktintreden van schoolverlaters in crisistijd te bevorderen zou kunnen zijn om de inschrijvingsgelden aan onderwijsinstellingen afhankelijk te maken van de stand van de conjunctuur. Dit zou met name mbo'ers extra kunnen aansporen om in crisistijd een vervolgopleiding te starten of hun studieduur te verlengen om ruimte te creëren voor bijvoorbeeld het volgen van extra vakken of een extra stage. Om hbo'ers hiertoe te stimuleren is het wellicht effectiever om de studiefinanciering te verlengen in perioden waarin het economisch slechter gaat. Ook zouden de voorwaarden voor leningen in het kader van het sociaal leenstelsel in crisistijd versoepeld kunnen worden. Daarbij is het wellicht wel raadzaam om te voorkomen dat schoolverlaters in crisistijd met hoge private schulden opgezadeld worden.

\section{Individuele leerrekening}

De ambitie van het huidige kabinet om de introductie van een individueel leer- en ontwikkelbudget vorm te geven wordt ondersteund door de bevindingen in het rapport van het eerste deelproject (Belfi et al., 2018). Daaruit blijkt immers dat de cursusdeelname in de erste jaren van iemands arbeidsloopbaan zowel op korte als middellange termijn leidt tot gunstigere arbeidsmarktperspectieven. Het invoeren van een individuele leerrekening zou eventueel gefocust kunnen worden op schoolverlaters, die vaak sterk getroffen worden in een periode van hoge conjuncturele werkloosheid.

\section{Subsidies en werktijdverkorting}

De cursusdeelname in het begin van de arbeidsloopbaan van mbo- en hbo-afgestudeerden heeft zowel op de korte als middellange termijn een gunstige invloed op iemands arbeidsmarktperspectieven. Door ervoor te zorgen dat werknemers in perioden waarin het economisch minder goed gaat toch door het volgen van cursussen en 
trainingen kunnen investeren in hun menselijk kapitaal, kan het nadelige effect van een crisisperiode op hun toekomstige arbeidsmarktperspectieven (deels) worden tegengegaan. Daarom kan het zinvol zijn om subsidies te geven aan bedrijven die schoolverlater in crisistijd trainingen aanbieden. Hetzelfde zou bereikt kunnen worden door de verbreding van het systeem van werktijdverkorting. In een crisisperiode zouden publieke middelen kunnen worden aangewend voor de bekostiging van bedrijfscursussen of trainingen voor werknemers die gedeeltelijk werkloos zijn.

\section{Levenslang leren}

Door de veroudering van kennis en de veranderingen in de vraag naar vaardigheden brengen is het in toenemende mate van belang dat werkenden en niet-werkenden investeren in hun kennis en vaardigheden. Het onderzoek laat zien dat men leert van deelname aan cursussen, maar vooral door de taken die men uitvoert op het werk (informeel leren).

\section{Harde kern}

Een harde kern van ruim een kwart van de werkenden heeft nog nooit een cursus gevolgd in zijn of haar arbeidsloopbaan. Dit maakt hen bijzonder kwetsbaar bij veranderingen in de op de arbeidsmarkt gevraagde kennis en vaardigheden. De vraag die dit oproep is hoe deze harde kern gestimuleerd zou kunnen worden om op dit punt een stap te zetten?

De harde kern van werkenden die nooit een training hebben gevolgd betreft vooral laagopgeleiden. Bij deze harde kern is er vaak sprake van een kloof tussen het leervermogen en de taken die ze op de werkvloer uitvoeren. Beleid om het leren van deze groep te stimuleren zou gericht moeten worden op het verkleinen van de barrières tot leren. Ten eerste, als er een cursus gevolgd moet worden, dan zou het kunnen helpen als deze cursus binnen het bedrijf in groepsverband wordt georganiseerd. In dat geval voelen medewerkers immers vaak een bepaalde verantwoordelijkheid voor collega's waarvoor de cursus moeilijk is. Ten tweede is het van belang om deze harde kern zoveel mogelijk praktijkgericht op de werkplek te laten leren, en het opleidingsaanbod aan te passen aan de mensen en de taken die concreet uitgevoerd moeten worden. Hieraan gekoppeld zou het vermoedelijk helpen om door het uitreiken van praktijkcertificaten een formele erkenning te geven aan wat iemand op deze wijze heeft geleerd. Ten derde, om de drempel tot leren te verminderen, is het aan te bevelen om leerstof in kleinere modules aan te bieden, gespreid over een langere tijdsperiode. Ten vierde zouden eenvoudige interventies (bijvoorbeeld een gesprek met een leeradviseur, manager, of leerambassadeur) ertoe kunnen leiden dat werkenden hun beeld ten aanzien van het volgen van scholing bijstellen en zich voor cursussen gaan aanmelden. Recent onderzoek op dit terrein laat echter geen eenduidig beeld zien van de effectiviteit van deze interventies, al zou dit kunnen liggen aan de kleine omvang van de onderzoeksgroep en de korte duur van de interventies (Bisschop et al., 2018). Ten vijfde willen wij wijzen op het belang van de rol van de directe leidinggevende als het om scholing gaat. Het is van 
belang dat leidinggevenden de juiste toon gebruiken omdat de term 'leren' sommige groepen werkenden eenvoudigweg afschrikt. Het is belangrijk dat er op het terrein van het leren en ontwikkelen een vertrouwensband ontstaat tussen een medewerker en zijn of haar leidinggevende. Dit maakt gesprekken hierover effectiever. Het vereist echter dat leidinggevenden zich meer bewust zijn van hun cruciale rol en goed opgeleid worden om het leren en ontwikkelen van hun medewerkers in goede banen te leiden. Door medewerkers mee te nemen en te betrekken bij de grote transities die zich nu in de economie voltrekken - en waaraan zowel bedrijven als hun medewerkers zich zullen moeten aanpassen - kunnen bedrijven er voor zorgen dat hun medewerkers zich meer eigenaar voelen van hun ontwikkelingsbehoefte.

\section{Vaardigheden en onderwijs}

lemands motivatie, persoonlijkheid en leefstijl is mede bepalend voor zijn of haar deelname aan scholing en/of informeel leren en het rendement daarvan. Daarom moet het onderwijsbeleid om een goed fundament te creëren voor het levenslang leren zich meer richten op het stimuleren van persoonlijkheids- en leefstijlkenmerken die positief samenhangen met leren.

Daarnaast signaleren veranderingen in de op de arbeidsmarkt gevraagde competenties de noodzaak tot aanpassingen in het curriculum van het initieel onderwijs, zeker als blijkt dat deze veranderingen tot competentietekorten leiden die moeilijk kunnen worden weggenomen door bijscholing op latere leeftijd. Interpersoonlijke en analytische vaardigheden zijn in toenemende belangrijk om in veel functies goed te kunnen functioneren. Het initieel onderwijs zou zich moeten richten op onderwijsvormen die de ontwikkeling van dergelijke vaardigheden stimuleren, zonder dat dit ten koste gaat van het leren van de vereiste vakspecifieke vaardigheden.

\section{Kennis in de praktijk brengen}

Het volgen van cursussen en trainingen alleen is niet voldoende om de inzetbaarheid op peil te houden. Ons onderzoek laat zien dat het volgen van cursussen alleen leidt tot een betere inzetbaarheid en een hoger loon als de op de cursus opgedane kennis en vaardigheden ook in de praktijk toegepast kunnen worden. Dit besef is van groot belang voor het verbeteren van het HR-beleid, omdat ongeveer een derde van de werknemers die een cursus hebben gevolgd, aangeeft dat ze de opgedane kennis op hun werk niet of nauwelijks in de praktijk hebben gebracht. Concreet betekent dit voor werkgevers, dat het cruciaal is om bij het aanbieden van cursussen aan hun medewerkers ervoor te zorgen dat de opgedane kennis daadwerkelijk in de praktijk gebracht kan worden, zodat het maximale rendement uit scholingsinvesteringen kan worden gehaald. Dit vereist een nauwe afstemming tussen het scholingsbeleid en de organisatie van het werk.

\section{Informeel leren}

Ons onderzoek laat zien dat het gros van de tijd waarin werkenden leren op het werk $(85 \%)$ betrekking heeft op informeel leren. Wat hieruit afgeleid kan worden vanuit beleidsoogpunt is dat werkenden veel kunnen leren als onderdeel van het werk dat zij 
doen. Ons onderzoek op basis van de Nederlandse Skills Survey laat zien dat, hoewel zowel de cursusdeelname als het informeel leren positief samenhangen met de taakeffectiviteit van werkenden, er in analyse waarin gecontroleerd voor selectie-effecten vooral het informeel leren tot een verbeterde taakeffectiviteit leidt. Dit onderstreept nog eens het belang van het informeel leren op het werk. In kleine bedrijven leren werkenden net zoveel van de taken die zij doen als in grote bedrijven. Daar staat echter tegenover dat de cursusdeelname in kleine bedrijven lager is dan in grote bedrijven. Voor kleine bedrijven betekent dit dat vooral zij goed moeten zoeken naar mogelijkheden om het werk zodanig te organiseren dat hun medewerkers de kans krijgen zich verder te ontwikkelen tijdens het uitvoeren van hun werkzaamheden.

Voor werkgevers en werknemers is het van belang om voldoende uitdaging in het werk te blijven houden. Door taakroulatie kan de werkgever er voor zorgen dat een werknemer verschillende skills blijft ontwikkelen en zijn of haar potentieel beter worden benut. Tegelijkertijd moeten medewerkers gestimuleerd worden om meer na te denken over hun takenpakket en bij hun leidinggevende duidelijk aan te geven welke andere taken zij in hun ogen ook goed zou kunnen doen. Ook hiervoor is de kwaliteit van de leidinggevenden en de vertrouwensrelatie die zij hebben met hun medewerkers weer van groot belang voor het creëren van een goed leerklimaat in de organisatie.

De beleidsuitdaging is hier dat de kennis die opgedaan wordt door het informeel leren gevalideerd dient te worden. Dit betekent dat het kennisniveau van medewewerkers goed gemonitord moet worden. Het probleem hierbij is echter vaak dat zowel bedrijven, werkenden als de taken die medewerkers hebben sterk van elkaar verschillen, waardoor het meten van iemands competentieniveau lastig is. Onderzoek zou kunnen helpen om meer zicht krijgen op een innovatieve aanpak die dit zou kunnen realiseren. Skills-apks en loopbaanchecks zouden goede instrumenten kunnen zijn, waarmee zicht wordt gekregen op de competenties die werkenden hebben en zouden kunnen ontwikkelen, de ruimte voor deze ontwikkeling in hun werk en mogelijke carrièrestappen. Een dergelijk beleidsinstrument is reeds ingevoerd door de Belgische VDAB (het equivalent van het UWV). Om effectief te kunnen zijn is een goede inbedding van de inzet van een dergelijk instrument in het HR-beleid van een organisatie ook van groot belang. Zo zou het goed zijn om een loopbaancheck te koppelen aan het functioneringsgesprek of persoonlijk ontwikkelplan.

\section{Kwetsbare groepen}

De vergrijzing van de beroepsbevolking, de upgrading van de werkgelegenheids-structuur en de flexibilisering van de arbeidsmarkt zorgen ervoor dat 55-plussers, laagopgeleiden en werknemers met een tijdelijk dienstverband vaak een kwetsbare positie op de arbeidsmarkt hebben. Het ontwikkelen van een goed levenslang leren beleid dat de duurzame inzetbaarheid van deze groepen werkenden verbetert en daarmee de Nederlandse kenniseconomie een impuls kan geven is belangrijk. Verschillende uitkom- 
sten van ons onderzoek bieden aanknopingspunten voor het ontwikkelen van het HR-beleid van arbeidsorganisaties en het overheidsbeleid op dit terrein.

\section{5-plussers}

Ons onderzoek laat zien dat 55-plussers zelf minder bereid zijn om scholing te volgen dan hun jongere collega's. Maar ook werkgevers blijken minder bereid te zijn om in de scholing van hun oudere medewerkers te investeren. Zodra werkgevers echter het gevoel krijgen dat oudere medewerkers in de organisaties gemotiveerd zijn om te leren, dan zijn ze bereid om deze groep scholing aan te bieden (zie De Künn-Nelen et al., 2018). Een verhoogde cursusbereidheid onder 55 -plussers stimuleert de cursusdeelname dus langs twee wegen: ze zijn zelf meer geneigd om scholing te volgen en hun werkgever is meer bereid om dit te faciliteren. In deze context is het zinvol om de motivatie van 55-plussers om hun competenties op peil te houden door het volgen van cursussen en trainingen op een aantal manieren te vergroten:

- De scholing tijdens werktijd aan te bieden.

- De financiering van de scholing geheel weg te halen bij de 55-plussers zelf.

- Taakroulatie aan te bieden.

- Coaching aan te bieden.

- 55-plussers te informeren over de grotere bereidheid van werkgevers om cursussen aan te bieden als werkgevers zien dat 55-plussers voldoende gemotiveerd zijn om te leren.

Voor een toename van de scholingsdeelname van 55-plussers is ook een goed gesprek tussen de werkgever en de werknemer nodig over de verdere loopbaanambities. ${ }^{5}$ In een dergelijk gesprek moet duidelijk besproken worden hoe lang de werknemer nog wil en/ of moet blijven werken. Het expliciet benoemen hiervan zorgt zowel bij de werkgever als bij de werknemer zelf voor de bewustwording dat het vaak nog loont om zich te blijven ontwikkelen. Een loopbaancheck kan daarbij helpen om inzichtelijk te maken wat nodig is om duurzaam inzetbaar te worden of te blijven.

\section{Lager opgeleiden}

De geringere scholingsdeelname van lager opgeleide werkenden blijkt vooral een gevolg te zijn van de lagere scholingsbereidheid van de werknemers zelf. Werkgevers zouden deze bereidheid kunnen vergroten door het voor deze groep aantrekkelijker te maken om scholing te gaan volgen en het urgentiebesef hiervan bij de lager opgeleiden te vergroten. Dit kan gedaan worden door:

- De scholing tijdens werktijd aan te bieden.

- De financiering van de scholing geheel weg te halen bij de laagopgeleide zelf.

5 De randvoorwaarden voor een dergelijk gesprek en meer in het algemeen de rol van de werkgever in het stimuleren van cursusdeelname komt later in dit hoofdstuk nog uitgebreid aan bod. 
- Feedback van collega's te stimuleren, waardoor de feedback van de leidinggevende kan worden beperkt.

- Het aanbieden van een persoonlijk opleidings- of ontwikkelplan.

- Het duidelijker benoemen van de noodzaak om zich te blijven ontwikkelen gegeven technologische ontwikkelingen in de sector, of om zich eventueel om te scholen als het werk te zwaar is om tot de pensionering vol te houden.

Maar zelfs als aan bovenstaande punten wordt voldaan is het nog niet vanzelfsprekend dat laagopgeleiden daadwerkelijk aangezet worden tot het volgen van scholing. Voor veel laagopgeleiden wordt het volgen van scholing immers geassocieerd met hun vroegere negatieve ervaringen in het initiële onderwijs.

Het is daarom van groot belang dat laagopgeleiden zelf ook inzien waarom het belangrijk is dat zij zich blijven ontwikkelen. Een loopbaanscan of competentiepaspoort kan hierbij een handig instrument zijn. Werknemers die veel routinewerk doen waarvoor de noodzaak tot scholing niet direct duidelijk is, moeten erop gewezen worden dat zij breder inzetbaar moeten zijn, mochten het werk dat zij doen verdwijnen. De werkgever is hierbij een belangrijke gesprekspartner ${ }^{6}$, maar laagopgeleiden zouden ook terecht moeten kunnen bij externe loopbaancentra en loopbaanadviseurs. Het zou mogelijk moeten zijn om scholingscheques of een individuele leerrekening ook in te zetten voor dergelijke doelen.

Daarnaast zou het introduceren van leerambassadeurs laagopgeleiden een duwtje in de rug kunnen geven om meer aandacht te hebben voor hun eigen ontwikkeling en duurzame inzetbaarheid. Leerambassadeurs zijn collega's die laagopgeleiden - mede op basis van hun eigen ervaringen - kunnen inlichten over hun opleidingsmogelijkheden en ze motiveren om er gebruik van te maken. In Engeland zijn er positieve ervaringen opgedaan met door de vakbond ondersteunde leerambassadeurs, die door de overheid bekostigd worden uit het 'union learning fund' (zie Coenen, 2018). Uit ons onderzoek bleek ook dat de feedback van collega's positief samenhangt met cursusdeelname van laagopgeleiden. Dit maakt het interessant om ook in Nederland te verkennen of leerambassadeurs het scholingsbewustzijn en de cursusdeelname van lager opgeleiden kunnen bevorderen. Daarbij is het belangrijk om te kijken welke factoren kunnen bijdragen aan een succesvolle inzet van leerambassadeurs.

Gezien het grote belang van het informele leren op de werkvloer is het ook wenselijk dat de op informele wijze verkregen kennis en vaardigheden erkend worden, waardoor deze kennis en vaardigheden voor andere werkgevers en opleidingsinstellingen zichtbaar gemaakt worden.? Het geven van praktijkcertificaten (bijv. EVCs) is een mogelijke

6 De manier waarop de werkgever dit in kaart kan brengen wordt later in dit hoofdstuk uitgebreid beschreven. Hierbij moet wel de kanttekening gemaakt worden dat laagopgeleiden minder leren van hun werk dan middelbaar- en hoogopgeleiden (zie Künn-Nelen et al. 2018, Hoofdstuk 1). Dit blijkt gedeeltelijk het gevolg te zijn van de (weinig leerzame) taken die zij uitvoeren (zie Künn-Nelen et al. 2018, Hoofdstuk 2). Om het ervaringsleren van lager opgeleiden goed van de grond te krijgen, zal geprobeerd moeten worden om hun werkomgeving leerrijker te maken. 
manier waarop de in de praktijk opgedane kennis gevalideerd kan worden. Op deze manier kan de opgedane kennis meegenomen worden naar andere bedrijven.

\section{Flexwerkers}

Ons onderzoek laat zien dat de cursusdeelname van werknemers met een tijdelijk contract zonder uitzicht op een vast dienstverband een stuk lager ligt dan onder werknemers met een vast of met uitzicht op vast dienstverband. Tijdelijke werknemers zonder uitzicht op een vast dienstverband blijken echter zeer gemotiveerd om scholing te volgen, maar werkgevers blijken beduidend minder bereid te zijn om hen scholing aan te bieden. Ons onderzoek laat zien dat de bereidheid van werkgevers om de training van flexwerkers te bekostigen op een aantal manieren zou kunnen worden vergroot:

- Een terugbetalingsverplichting waardoor werkgevers scholingskosten (gedeeltelijk) terugkrijgen van de werknemer als deze ruim voor de afloop van het contract vertrekt. In dat geval ervaren werkgevers minder onzekerheid over de mate waarin ze de door hen geïnvesteerde scholingskosten kunnen terugverdienen.

- Werknemers met een tijdelijk contract zonder uitzicht op een vaste aanstelling geven daarnaast aan graag een cursus gericht op loopbaanoriëntatie en coaching te willen volgen. Werkgevers zijn echter veel minder bereid dergelijke cursussen aan te bieden dan cursussen gericht op vaktechnische kennis en vaardigheden. Opleidingsfondsen eventueel in samenwerking met de overheid zouden een rol kunnen spelen bij het vergroten van de cursusdeelname van tijdelijke werknemers zonder uitzicht op een vast dienstverband door hen een individuele leerrekening of scholingscheque te geven.

Het is echter wel belangrijk op te merken dat alleen het introduceren van een individuele leerrekening of scholingscheque niet genoeg is. ${ }^{8}$ Ook voor flexwerkers is het van belang dat zij ondersteund worden bij de besteding van een dergelijk budget. ${ }^{9}$ Hiervoor kan een loopbaancheck erg behulpzaam zijn, maar er zijn ook mogelijkheden voor lichtere interventies. Zo heeft het O\&O fonds OOM voor de werkenden in metaalbewerkingsbedrijven een online catalogus ontwikkeld om hen op weg te helpen bij het vinden van een geschikte scholing. Een loopbancheck zou ook goed ondersteund kunnen worden door een digitale tool, waarin iemands eigen competenties inzichtelijk gemaakt worden én een aanbod van trainingen opgenomen is die iemands competentieprofiel kan versterken.

- De huidige transitievergoeding zou naar voren gehaald moeten worden en ingezet moeten worden voor scholing die de inzetbaarheid van flexwerkers vergroot. Dat is veel efficiënter dan als het pas uitbetaald wordt na afloop van de contractperiode. Zo zouden mensen met een tijdelijk contract per half jaar bijvoorbeeld een week salaris moeten kunnen besteden aan scholing. Op deze manier kunnen flexwerkers

8 Dat een enkele regeling niet voldoende is om de scholingsdeelname van werkenden met een kwetsbare positie op de arbeidsmark te vergroten wordt later in dit hoofdstuk uitgebreid besproken als wordt ingegaan op het belang van een goed leerklimaat.

9 Eerder is dit ook al geconstateerd voor 55-plussers en laagopgeleiden. 
gedurende de looptijd van een tijdelijk contract werken aan het verbeteren van hun inzetbaarheid op de arbeidsmarkt.

- Flexwerkers moeten ook door hun werkgever geholpen worden met hun scholingskeuzes. Het is immers voor velen niet makkelijk te bepalen welke scholing voor hen het meest nuttig zal zijn na afloop van hun lopende contract. Uitzendbureaus zouden op dit punt een zeer waardevolle rol kunnen spelen om de duurzame inzetbaarheid van flexwerkers te versterken.

Meer in het algemeen is het belangrijk dat de opleidingsinfrastructuur in sectoren waart veel flexwerkers werkzaam zijn, zoals de bouw, de horeca en detailhandel weer hersteld wordt nadat deze de afgelopoen jaren in de economische crisis ster is geërodeerd.

\section{Ankerpunten voor het HR- en overheidsbeleid}

Tot slot van dit rapport willen we ingaan op wat de drie belangrijkste ankerpunten zouden kunnen zijn waarop het beleid gericht op het "Leven lang ontwikkelen" zich zou moeten richten. Daarbij onderscheiden we de volgende drie elkaar versterkende ankerpunten:

- De rol van de werkgever

- Individuele leerrekeningen of scholingscheques

- Een leerrijk werkklimaat

We spreken hier van ankerpunten omdat veel van de hierboven genoemde specifieke instrumenten binnen dit raamwerk passen, maar in de praktijk ook om nadere uitwerking vragen. Ook komen de individuele leerrekeningen of cheques duidelijk naar voren als een mogelijke game-changer, die zowel in het algemeen als voor de specifieke doelgroepen een belangrijke rol kan gaan vervullen in de vereiste infrastructuur voor het versterken van de duurzame inzetbaarheid van de werkzame bevolking. Ten slotte is een leerrijk werkklimaat een erg belangrijk overkoepelend begrip dat aangeeft dat het effect van specifieke beleidsinstrumenten doorgaans erg klein zal zijn als deze geen onderdeel uitmaken van een integraal beleid gericht op de competentieontwikkeling van de medewerkers.

Deze ankerpunten sluiten goed aan bij ambitie die het kabinet heeft om een doorbraak te realiseren op het gebied van het leven Lang Ontwikkelen, zoals recentelijk kenbaar is gemaakt in de brief van de Ministers van SZW en OCW aan de Tweede Kamer (Ministerie Sociale Zaken en Werkgelegenheid, 2018).

\section{De rol van de werkgever}

Evenals voor de andere medewerkers, is voor alle werkenden met een kwetsbare positie op de arbeidsmarkt de rol van hun werkgever van groot belang voor het stimuleren van hun scholingsdeelname en informele leren. Zoals bij de laagopgeleiden duidelijk blijkt, is het niet altijd voldoende als werkgevers scholing aan hun medewerkers aanbieden. 
Hoewel er vanzelfsprekend ook een verantwoordelijkheid bij de werknemers zelf ligt, doen werkgevers er goed aan om in hun HR-beleid de scholingsbereidheid van hun werknemers te optimaliseren.

Allereerst, zouden werkgevers hun werknemers inzichtelijk moeten maken waarom een leven lang ontwikkelen belangrijk voor hen is. Zo moet de werkgever werknemers blijven vragen waar zij over twee jaar willen staan, zodat gezamenlijk bekeken kan worden hoe realistisch dit is en wat hier voor nodig is. Ook de werkgever moet aan de werknemer duidelijk maken waar het bedrijf over een aantal jaren wil staan en wat dit vraagt van de werknemers. Op basis van deze informatie zou voor iedere medewerker om de twee of drie jaar een opleidings- of ontwikkelplan moeten worden opgesteld dat jaarlijks wordt gemonitord. Het koppelen van een doel aan het leren maakt het voor zowel de werkgever als de werknemer inzichtelijker wat er op leergebied gedaan moet worden.

Bedrijven zouden hierbij ook baat hebben bij een overkoepelend bedrijfsopleidingsplan. Hierbij zou het MKB ondersteund kunnen worden door hun werkgevers-vereniging, opleidingsfondsen en/of externe adviseurs.

Daarnaast zouden werkgevers in hun organisatie een leerrijke werkomgeving moeten creëren. Hierbij is het belangrijk dat de leidinggevenden de juiste attitude ten opzichte van leren moet uitstralen. Ook is het van belang dat de werkgever een veilige omgeving mogelijk maakt waarin fouten gemaakt mogen worden. Daarnaast is het belangrijk om voldoende dynamiek in het takenpakket van werkenden te houden en te voorkomen dat iemand vastroest in een takenpakket waarvan hij- of zij nog maar weinig leert. Dit vereist dat werkgevers voldoende aandacht hebben voor functieroulatie en taakroulatie, mede gerelateerd aan de loopbaanfase waarin iemand zit (zie De Grip \& Iske, 2012). Dit geeft overigens niet alleen een belangrijke impuls aan het informele leren op het werk, maar het verbreedt ook de inzetbaarheid van medewerkers waaraan veel werkgevers ook behoefte hebben (zie Dijksman et al., 2018).

\section{Individuele leerrekeningen of scholingscheques}

Individuele leerrekeningen of scholingscheques sluiten goed aan bij de ambitie van het kabinet om de eigen regie van mensen op het terrein van het levenslang leren te versterken (ministerie SZW, 2018). De uitkomsten van ons onderzoek laten zien dat individuele leerrekeningen of scholingscheques ook gunstig kunnen uitwerken voor werkenden met een kwetsbare positie op de arbeidsmarkt, waarvan de scholingsdeelname laag is. Enerzijds omdat werkgevers minder bereid zijn om te investeren in de ontwikkeling van 55-plussers en de werkenden met een tijdelijk contract zonder uitzicht op een vaste aanstelling. Anderzijds omdat lager opgeleiden en 55-plussers zelf minder bereid zijn om een cursus te gaan volgen en ze door het endowment effect ${ }^{10}$ van een volgen van een scholing (zie Kahneman \& Tversky (1979). 
scholingscheque of individuele leerrekening dit sneller zullen gaan doen. Dit endowment effect treedt echter alleen op als de financiële middelen die de scholingscheque of individuele leerrekening biedt een beperkte geldigheidsduur heeft. Om toch ook de mogelijkheid te bieden op te sparen voor het volgen van een wat langere cursus of training zou gedacht kunnen worden aan een geldigheidsduur van bijvoorbeeld 3 jaar. Belangrijk hierbij is dat er goede afspraken worden gemaakt over de bestemming van de opgebouwde middelen na die periode, dit laatste heeft ook belangrijke fiscale consequenties.

Het gebruik van een individuele leerrekening of scholingscheque kan worden gestimuleerd door de mogelijkheid te bieden het beschikbare budget in te zetten voor het betalen van de cursusgelden en/of voor werktijd waarin men de training kan volgen (zie Fleuren et al., 2018). De uitkomsten van ons onderzoek laten ook zien dat de mogelijkheid om de cheque te besteden aan zowel de cursusgelden als het vrijkopen van werktijd belangrijk is, omdat beide een belemmering om de scholing te gaan volgen kunnen wegnemen. Bij de kwetsbare groepen is het vrijkopen van werktijd vooral belangrijk om de scholingsdeelname van lager opgeleiden en 55-plussers te stimuleren. Ook blijken werknemers met thuiswonende kinderen vooral minder bereid te zijn een cursus te volgen als ze dat in hun eigen tijd moeten doen. Voor hen zou het dus aantrekkelijk zijn om met hun scholingscheque werktijd vrij te kunnen kopen. Een alternatief is dat de scholingscheque besteed kan worden aan de trainingskosten en werknemers een aantal dagen per jaar scholingsverlof krijgen, die ze over een periode van bijvoorbeeld drie jaar kunnen opsparen.

Ook is het wenselijk dat een individuele leerrekening of scholingscheque ruime bestedingsmogelijkheden heeft. Zo geven werkenden met een tijdelijk contract zonder uitzicht op een vaste aanstelling aan vooral behoefte te hebben aan cursussen en trainingen gericht op loopbaanoriëntatie en coaching. Daarnaast kan het inwinnen van advies over de richting waarin men zich het beste kan ontwikkelen ook voor laagopgeleiden nodig zijn. Bekostiging van een ontwikkelings- of loopbaanadvies zou ook vanuit een cheque of individuele leerrekening mogelijk moeten zijn.

Hoewel het up-to-date houden van de competenties van werkenden in belangrijke mate de primaire verantwoordelijkheid is van de werkenden zelf, is het belangrijk dat zij bij het inzetten van de middelen op hun individuele leerrekening ondersteund worden door gebruik te kunnen maken van loopbaancheck of adviezen van leerambassadeurs. Maar zoals hierboven al werd aangegeven is het ook van groot belang dat werkgevers in hun organisatie een leerklimaat creëren, waarbinnen het vanzelfsprekend is dat medewerkers gebruik maken van hun leerrekening of cheque. Daarom is het ook belangrijk dat scholingscheques of stortingen op de individuele leerrekening onderdeel worden van de in de C.A.O. vastgelegde arbeidsvoorwaarden.

De uitkomsten van deelproject 3 laten echter zien dat werkgevers minder bereid zijn om te investeren in de scholing van 55 -plussers en medewerkers met een tijdelijk contract 
zonder uitzicht op een vaste aanstelling. Bij de 55-plussers schatten werkgevers de gemiddelde leermotivatie en het gemiddelde leervermogen lager in dan bij jongere medewerkers. Bij de tijdelijke medewerkers zijn werkgevers vooral bevreesd dat deze al voor het aflopen van hun contract elders gaan werken. De overheid zou hier een meer actieve rol kunnen spelen om de scholingsparticipatie van deze kwetsbare groepen te stimuleren (Zie ook: Van Breugel et al., 2011). Een belangrijk punt daarbij is de fiscale belastbaarheid van de stortingen op de individuele leerrekeningen en het verstrekken van de scholingscheques aan flexwerkers die niet bij het bedrijf zelf in dienst zijn.

Tabel 5.1 geeft een overzicht van een aantal verschillen tussen individuele leerrekeningen en scholingscheques. Beide regelingen zijn in principe belastingplichtig, echter bij de individuele leerrekening is een vrijstelling, onder bepaalde voorwaarden, mogelijk. De regelgeving omtrent scholingscheques is minder duidelijk en vereisen in de praktijk ook een consultatie van de Belastingdienst, maar ook hier lijken vrijstellingen mogelijk.

TABEL 5.1 Verschillen tussen individuele leerrekening en scholingscheque

\begin{tabular}{|c|c|c|}
\hline & Individuele leerrekening & Scholingscheque \\
\hline Belastingplichtig & $\begin{array}{l}\text { Vrijstelling mogelijk (mits besteding conform } \\
\text { een van de vrijstellingen in de loonheffingen) }\end{array}$ & $\mathrm{Ja}$ \\
\hline Stortingen & $\begin{array}{l}\text { Meerdere partijen: } \\
\text { bijv. werkgever, } 0 \& 0 \text { fondsen, werknemer, } \\
\text { overheid } \\
\text { Periodieke stortingen mogelijk }\end{array}$ & $\begin{array}{l}\text { Meestal één partij: } \\
\text { bijv. bedrijf, sector of overheid } \\
\text { (uitzonderingen: een cheque uit een } \\
\text { fonds aangevuld door werkgever, } \\
\text { combinatie van cheques uit fonds en } \\
\text { overheid) } \\
\text { Eenmalig }\end{array}$ \\
\hline Aard & $\begin{array}{l}\text { Sparen mogelijk om hoger budget te krijgen } \\
\text { voor duurdere trainingen (wel is besteding } \\
\text { binnen } 6 \text { jaar nodig voor de fiscale vrijstelling) }\end{array}$ & $\begin{array}{l}\text { Eenmalig bedrag dat beperkte tijd } \\
\text { geldig is (soms kunnen meerdere } \\
\text { jaarlijkse cheques ook gecombineerd } \\
\text { worden door te sparen) }\end{array}$ \\
\hline Prikkel & Minder druk om geld te besteden & $\begin{array}{l}\text { Endowment effect stimuleert om de } \\
\text { cheque te besteden }\end{array}$ \\
\hline Bestedingsdoelen & $\begin{array}{l}\text { Geen functiegerichte scholing, maar scholing } \\
\text { gericht op duurzame inzetbaarheid }\end{array}$ & $\begin{array}{l}\text { Wordt bepaald door financier van de } \\
\text { scholingscheque }\end{array}$ \\
\hline Meenemen naar andere werkgever & $\begin{array}{l}\text { Ja } \\
\text { Dit maakt het zeer geschikt voor flexwerkers }\end{array}$ & Vaak niet \\
\hline Verwachte effectiviteit & $\begin{array}{l}\text { Werkt mogelijk goed voor doelgroepen met een } \\
\text { hogere scholingsmotivatie: } \\
\text { middelbaar en hoger opgeleiden, flexwerkers } \\
\text { en jongeren }\end{array}$ & $\begin{array}{l}\text { Werkt mogelijk goed voor doelgroepen } \\
\text { met lagere scholingsmotivatie: } \\
\text { Laag opgeleiden en } 55 \text {-plussers }\end{array}$ \\
\hline
\end{tabular}

De individuele leerrekening heeft als voordeel dat meerdere partijen middelen op deze rekening kunnen storten. Zo kan een deel van het brutosalaris van werknemers gecombineerd worden met een bijdrage van de werkgever, opleidingsfondsen en eventueel 
ook de overheid. Scholingscheques worden daarentegen meestal door één partij bekostigd en uitgereikt, hoewel het ook voorkomt dat verschillende cheques worden gecombineerd, of dat de werkgever een cheque aanvult als een scholing niet volledig uit de cheque bekostigd kan worden. Terwijl bij een individuele leerrekening periodieke stortingen mogelijk zijn, is een scholingscheque in principe eenmalig. Echter, soms kunnen meerdere jaarlijkse cheques ook gecombineerd worden door te sparen. Bij een individuele leerrekening gaat het sparen bijna automatisch, waardoor het mogelijk is om een hoger budget te krijgen die het mogelijk maakt om een duurdere en/of langer durende scholing te gaan volgen. Besteding binnen 6 jaar is echter wel nodig om aan de voorwaarden voor vrijstelling te voldoen. Als gevolg van het spaarkarakter en de lange houdbaarheid van de individuele leerrekening, is er minder druk om de individuele leerrekening ook daadwerkelijk te gebruiken voor scholing. Het is op deze manier makkelijk om de scholing op de lange baan te schuiven. Door de, over het algemeen, beperkte geldigheid van scholingscheques is de druk om daadwerkelijk een cursus of training te gaan volgen hoger. Dit wordt versterkt door het endowment effect: het verloren gaan van een bezit (de scholingscheque) heeft een grotere impact dan het mogelijk iets kunnen bezitten dat je nu niet bezit (bijvoorbeeld een hoger toekomstig inkomen of grotere baanzekerheid door het volgen van een scholing (zie Kahneman \& Tversky (1979).

Een individuele leerrekening of scholingscheque komt vooral tot zijn recht als het niet ingezet mag worden voor functiegerichte scholing. Een individuele leerrekening is immers bedoeld om de werkenden te stimuleren aan scholing deel te nemen en niet om de scholing die hoe dan ook nodig is om de eigen functie goed uit te kunnen voeren te subsidiëren. De individuele leerrekening zou bij voorkeur gebruikt moeten worden voor leeractiviteiten gericht op de duurzame inzetbaarheid van de medewerker. Hiertoe behoren ook coaching en loopbaanadvies. De bestedingsdoelen voor een scholingscheque worden in de praktijk vastgelegd door de financier van de cheque. Bedrijven die deze cheques aan hun medewerkers verstrekken stimuleren vaak ook om de cheque in te zetten voor leeractiviteiten gericht op het verbeteren van de duurzame inzetbaarheid van hun medewerkers (bijvoorbeeld de E-miles van Philips; zie Gerards et al., 2014), maar er zijn ook andere bestedingsdoelen mogelijk.

Een ander verschil tussen beide regelingen is dat een individuele leerrekening meegenomen kan worden naar een andere werkgever en een scholingscheque vaak niet.

Het is vooraf niet mogelijk om te bepalen welke regeling voor groepen werkenden het meest effectief is. Echter, het is te verwachten dat doelgroepen met een lagere motivatie om scholing te gaan volgen meer baat hebben bij een scholingscheque. Enerzijds omdat een individuele leerrekening uitstel van scholing mogelijk maakt en anderzijds omdat bij een cheque het eerdergenoemde endowment effect optreedt. Echter, de hoogte van de cheque, de scholingskosten en de toegestane bestedingsdoelen spelen ook een rol bij de effectiviteit van een cheque voor werkenden met een relatief lage scholingsmotivatie. Voor flexwerkers lijkt een individuele leerrekening het meest 
geschikt te zijn, omdat zij dan het gespaarde geld (binnen de 6 jaar) mee kunnen nemen als zij van werkgever veranderen.

Nader onderzoek is echter nodig om de precieze effectiviteit van zowel individuele leerrekeningen als scholingscheques voor specifieke doelgroepen te bepalen en in kaart te brengen welke factoren daarbij een rol spelen.

\section{Leerrijk werkklimaat}

Hoe waardevol een individuele leerrekening of scholingscheque ook kan zijn bij het stimuleren van scholingsdeelname onder werkenden (met en zonder een kwetsbare positie op de arbeidsmarkt), met alleen een dergelijke regeling ben je er niet. Uit ervaringen met bestaande cheques blijkt dat het vaak enige tijd duurt voordat het gebruik van een cheque aanslaat. Ook omdat zowel werkenden als hun lijnmanagers te vaak onvoldoende inzien hoe belangrijk het voor iemand kan zijn om zich bij te scholen.

Ons onderzoek en de bespreking daarvan op de beleidsconferentie (zie Bijlagen 1 en 2) laten zien dat er een cultuuromslag nodig is om het een leven lang ontwikkelen in Nederland van de grond te krijgen. We hebben een leercultuur nodig, waarin werkgevers én werknemers zich bewust zijn van de sterk toegenomen noodzaak tot een leven lang ontwikkelen vanwege de drie geschetste maatschappelijke ontwikkelingen:

\section{- Snelle veranderingen in de gevraagde competenties:}

De upgrading van de werkgelegenheidsstructuur en de verschuivingen in de op de arbeidsmarkt gevraagde competenties als gevolg van de technologische ontwikkelingen en de mede daaraan gerelateerde veranderingen in de organisatie van het productie- en dienstverleningsproces in alle sectoren van de arbeidsmarkt.

- Verlenging van de arbeidsloopbaan:

Het verlengen van de arbeidsloopbaan door het naar achteren schuiven van de pensioneringsleeftijd, waardoor de beroepsbevolking vergrijst.

- Flexibilisering van de arbeidsmarkt:

De sterke toename van meer flexibele arbeidsrelaties die de binding tussen werkgevers en werknemers verzwakt.

Het informele leren op het werk door de taken die men verricht en de feedback die collega's elkaar op de werkvloer geven vormt de basis van een goede leercultuur in een organisatie. Dat maakt het van groot belang dat medewerkers taken hebben die hen voldoende uitdagen en voorkomen wordt dat ze louter op basis van routine gaan werken voorkomen en op den duur vastroesten in een takenpakket waarvan zij nog maar weinig leren. Zoals hierboven al werd aangegeven vereist dit veel aandacht voor de mogelijkheden tot functie- en taakroulatie.

Een goede leercultuur vereist ook een veilige leeromgeving. Men moet fouten durven en mogen maken en niet aarzelen om aan collega's vragen te stellen als men iets onvol- 
doende snapt. Ook leerambassadeurs binnen het bedrijf, die zelf ervaren hebben hoe belangrijk scholing en informeel leren kunnen zijn voor iemands duurzame inzetbaarheid, kunnen mogelijk een waardevolle rol vervullen bij het versterken van de leercultuur binnen de organisatie. Ook moet er een open dialoog plaatsvinden tussen de medewerkers en hun leidinggevenden in opleidings- en ontwikkelgesprekken waarin de loopbaanambities, - perspectieven en de vereiste bij- of omscholing worden besproken. Het stellen van concrete doelen aan het leren maakt het voor zowel de werknemer als de werkgever inzichtelijk wat iemand moet leren om optimaal inzetbaar te blijven binnen de organisatie war men werkzaam is of daarbuiten.

Een leerrijk werkklimaat moet gecreëerd worden en daar is tijd voor nodig. In de recente brief van de Ministers van SZW en OCW aan de Tweede Kamer wordt terecht opgemerkt dat ieders inzet nodig is. De overheid, werkgevers, opleidingsfondsen, onderwijsinstellingen én de werknemers zelf zullen allemaal een belangrijke bijdrage moeten leveren aan de ontwikkeling van een goede leercultuur in alle sectoren van de economie. Brancheorganisaties en opleidingsfondsen kunnen daarbij een belangrijke rol vervullen bij het ondersteunen van de ontwikkeling van een leercultuur in het midden- en kleinbedrijf. Bijvoorbeeld door een scan te maken van de employability van het personeelsbestand van een organisatie en het leerklimaat in de organisatie. Gelukkig worden er in veel organisaties al belangrijke stappen gezet om een goede leercultuur van de grond te krijgen, maar het is goed om te beseffen dat het vrijwel overal nog in de kinderschoenen staat.

Maar ook voor de Nederlandse samenleving als geheel is het van groot belang om de leercultuur te versterken. Goede relaties tussen onderwijsinstellingen en hun alumni kunnen daar een belangrijke rol in vervullen. Ook de in het recente bestuursakkoord tussen het Ministerie van OCW en de MBO Raad vastgelegde ambitie om het scholingsaanbod van volwassenen beter te laten aansluiten op de behoeften van volwassenen kan daarbij een belangrijke rol vervullen.

\section{De betekenis van onderzoek}

Het is evident dat het ontwikkelen van een goede infrastructuur voor het leven lang ontwikkelen in Nederland met de daarbij vereiste ontwikkeling van een goede leercultuur een majeure inspanning vergt van alle betrokken organisaties. Het is dan ook terecht dat het kabinet een meerjarig programma heeft ontwikkeld om dit van de grond te krijgen.

Hoewel er veel consensus is over de vereiste pijlers voor een HR-beleid en overheidsbeleid gericht op het bevorderen van het levenslang leren van de beroepsbevolking, beseft iedereen dat het een lange weg zal zijn om de vereiste infrastructuur en cultuuromslag te realiseren. Dit wordt mede veroorzaakt door het feit dat we onvoldoende weten hoe effectief bepaalde instrumenten zijn en door welke factoren deze effectiviteit kan worden beïnvloed. 
Een goede onderzoekagenda op het terrein van het Leven Lang Ontwikkelen kan de komende jaren een belangrijke bijdrage leveren aan het versterken van het beleid en het versnellen van de vereiste ontwikkelingen. Dit vereist onderzoek op een tweetal terreinen:

\section{- Monitoring:}

Het goed blijven monitoren van de ontwikkelingen in de scholingsdeelname en het informeel leren van de Nederlandse beroepsbevolking en de factoren die dit stimuleren of belemmeren. De ROA levenslang leren enquête biedt hiervoor goede mogelijkheden.

Het goed blijven monitoren van de verschuivingen in de werkzaamheden die zich op de arbeidsmarkt voordoen. Het Nederlandse Skills Survey biedt hiervoor goede mogelijkheden.

Doordat beide enquêtes gekoppeld zijn aan het LISS-panel van de Universiteit van Tilburg beschikken we in Nederland over unieke mogelijkheden om de competentieverschuivingen die zich voordoen aan de vraagzijde van de arbeidsmarkt door de verschuivingen die er optreden in het takenpakket van de werkenden te relateren aan de leeractiviteiten van de Nederlandse beroepsbevolking, die daarop moeten inspelen.

- Onderzoek naar wat werkt en waarom:

Zowel binnen bedrijven als op sector- en regionaal niveau zijn er al tal van initiatieven gericht op het 'Leven Lang Ontwikkelen'. Het betreft echter meestal pilots die niet tot nauwelijks geëvalueerd (kunnen) worden, waardoor vaak het wiel opnieuw moet worden uitvonden. Om dit laatste te voorkomen is het van groot belang dat er reeds voor de start van nieuwe initiatieven goed wordt nagedacht op welke wijze de interventie goed kan worden geëvalueerd. Hoewel dit niet altijd makkelijk is, zijn er goede voorbeelden hoe dit in de praktijk zou kunnen (De Grip \& Sauermann, 2012; Hidalgo et al., 2014 en Fleuren et al., 2018).

Goed onderzoek naar de effecten van interventies maakt het niet alleen mogelijk dat een goed beeld wordt verkregen van wat werkt, het biedt ook perspectieven om een goed beeld te krijgen van waarom een bepaalde interventie goed werkt en bij welke opzet het beste resultaat wordt bereikt (zie bv. Fleuren et al., 2018). Daarbij kan het interessant zijn experimenten te relateren aan het monotoringsonderzoek, om op die manier een goede controlegroep te kunnen waarborgen (zie Schwerdt et al., 2012). 


\section{LITERATUUR}

Belfi, B., Allen, J., Eldert, P. van, Grip, A. de, Künn-Nelen, A.,Peeters, T. \& Poulissen, D. (2018). Schoolverlaters in crisistijd: gevolgen voor leren en de vroege loopbaan, ROA-R-2018/7, Maastricht. Berg, E. van den, Eldert, P. van, Fouarge, D., \& Weel, B. ter (2018). Taken en vaardigheden op het werk. Bevindingen uit de eerste en tweede Nederlandse Skills survey. Maastricht: ROA-R-2018/6.

Berge, W. Van den, \& Weel, B. ter (2015). Baanpolarisatie in Nederland. CPB Policy Brief 2015/13.

Bijlsma, I., Dijksman, S., Fouarge, D. \& Künn-Nelen, A. (2015). Winnaars en verliezers op de arbeidsmarkt 1996-2012. Tijdschrift voor Arbeidsvraagstukken, 31(2): 106-123.

Bisschop, P., Ouwehand, T., Weel, B. ter \& Zwetsloot, J. (2018). Post-initiële scholing stimuleren met kleine interventies. Tijdschrift voor Arbeidsvraagstukken, 34(3): 314-337.

Breugel, G. van, Grip, A. de \& Dohmen, D. (2011). Ontwikkelingscheque, Uitwerking Advies Denktank Leren en Werken, ROA-R-2011/3, Maastricht.

Coenen, I. (2018). Vakbondswerk maken van scholing en ontwikkeling, Zeggenschap 2018/3, 40-42.

Dijksman, S., Gerards, R., Grip, A. de, Peeters, T., Eldert, P. van \& Veth, J. (2018). Jaarrapportage Arbeidsmarktmonitor Metalektro 2017, Stichting A+O Metalektro, Hazerswoude-Dorp

Eldert, P. van, Fouarge, D., \& Künn-Nelen, A. (2018). Cursusdeelname, inzetbaarheid en lonen. Tijdschrift voor Arbeidsvraagstukken, 34(3), 340-354.

Fleuren, B.P.I., Grip, A. de, Kant, IJ \& Zijlstra, F. R. H. (2018). Time equals money? A randomized field experiment on four types of training vouchers, Maastricht University (mimeo).

Fouarge, D., Eldert, P. van, Grip, A. de, Künn-Nelen, A. \& Poulissen, D. (2018). Nederland in leerstand, ROA-R- 2018/4, Maastricht.

Gerards, R., Grip, A. de \& Witlox, M. (2014). "Employability-miles" and worker employability awareness. Applied Economics, 46, 952-965.

Grip, A. de \&Iske, P. (2012). Taakroulatie in plaats van functieroulatie. Gids voorPersoneelsmanagement, $91(7 / 8), 18-20$.

Grip, A. de \& Sauermann, J. (2012). The effects of training on own and co-worker productivity: evidence from a field experiment. Economic Journal, 122, 376-399

Hidalgo, D., Oosterbeek, H. \& Webbink, D. (2014). The impact of training vouchers on low-skilled workers. Labour Economics, 31, 117-128.

Kahneman, D., \&Tversky, A. (1979). Prospect Theory: An analysis of Decision under Risk, Econometrica, 47(2), 263-292.

Künn-Nelen, A., Eldert, P. van, Fouarge, D., Grip, A. de \& Poulissen, D. (2018). Leren onder werkenden met een kwetsbare positie op de arbeidsmarkt, ROA-R- 2018/5, Maastricht.

Ministerie van Sociale Zaken en Werkgelegenheid (2018). Leven Lang Ontwikkelen. Brief aan de Tweede Kamer, Den Haag, 27 september 2018. 
Poulissen, D., Künn-Nelen, A., Fouarge, D. \& Grip, A. de (2018), Trainingsparticipatie van oudere werknemers: Belemmeringen aan de vraag-en aanbodzijde van de arbeidsmarkt, Netspar Industry paper (nog te verschijnen).

Schwerdt, G., Messer, D., Woessmann, L. \& Wolter, S. (2012). The impact of an adult education voucher program: Evidence from a randomized field experiment. Journal of Public Economics, $96,569-583$ 


\section{BIJLAGE 1: PROGRAMMA BELEIDSCONFERENTIE 'LEVEN LANG ONTWIKKELEN EN COMPETENTIEONTWIKKELING}

Datum: Donderdag 27 september 2018

Locatie: Bezuidenhoutseweg 6o SER, Den-Haag

Dagvoorzitter Simone van Trier

13.00-13.15: Opening: Mariëtte Hamer (SER)

13.15-14.00: Presentaties door onderzoeksteam

- Barbara Belfi (ROA): Schoolverlaters in crisistijd: gevolgen voor leren en de vroege loopbaan.

- Didier Fouarge (ROA): Nederland in leerstand

- Annemarie Künn-Nelen (ROA): Leren onder kwetsbare groepen

- Bas ter Weel (SEO): Taken en vaardigheden op het werk

14.00-14.15: Inleiding beleidsrapport en tafelgesprekken

- Andries de Grip: Beleidsaanbevelingen en vragen voor rondetafelgesprekken

14.15-15.00: Rondetafelgesprekken

- Beleidsvragen worden besproken aan 6 ronde tafels

15:00-15:30: Pauze

15.30-16.00: Samenvatting rondetafelgesprekken

16.00-16.50: Paneldiscussie Leven lang ontwikkelen o.l.v. Mariëtte Hamer (SER)

- Gert-Jan Buitendijk (DG Werk Ministerie SZW)

- Gertrud van Erp (VNO-NCW/MKB Nederland)

- Isabel Coenen (FNV)

16:50-17:00: Afsluiting: Andries de Grip (ROA) 



\title{
BIJLAGE 2: RONDETAFELDISCUSSIES BELEIDSCONFERENTIE: BELEIDSVRAGEN EN DEELNEMERS
}

\author{
Tafel 1: Beleidsvragen
}

- De lage scholingsparticipatie van flexwerkers is vooral het gevolg van de geringere bereidheid van werkgevers om in flexwerkers te investeren. Flexwerkers hebben bovendien vaak behoefte aan een cursus gericht op loopbaanoriëntatie en coaching om effectief naar een nieuwe baan te kunnen doorstromen.

Welk beleid zou er op dit punt gevoerd kunnen worden?

- De lage scholingsparticipatie van laagopgeleiden is vooral het gevolg van hun geringere bereidheid om te investeren in hun inzetbaarheid, al zijn ze vaak wel gevoelig voor de condities waaronder scholing kan worden gevolgd. Welk beleid zou er op dit punt gevoerd kunnen worden?

\section{Deelnemers}

- Annemarie Künn-Nelen (voorzitter) - ROA/UM

- Dirk Scheele - Ministerie SZW

- Hans de Goede - Ministerie OCW

- Ronald Dekker - Ministerie SZW

- Marc van de Meer - Universiteit Tilburg

- Renske Hamstra - SBB

- Jose Leenders-OOM

- Ria van het Klooster - NRTO

\section{Tafel 2: Beleidsvragen}

- $25 \%$ van de werkenden heeft na het verlaten van het initieel onderwijs nog nooit een cursus of training gevolgd. Vaak gaat het om laag-opgeleiden met een kwetsbare positie op de arbeidsmarkt.

Hoe zou deze harde kern kunnen worden gestimuleerd om op dit punt een stap te zetten? 
- De lage scholingsparticipatie van oudere werkenden is zowel het gevolg van de geringere bereidheid van werkgevers om in hen te investeren als van de korte terugverdientijd die het voor de werkenden onaantrek-kelijk maakt. Welk beleid zou er op dit punt gevoerd kunnen worden?

\section{Deelnemers}

- Davey Poulissen (voorzitter) - ROA/UM

- Annie Kempers-Warmerdam - Examenkamer

- Josje Lesterhuis - SBCM

- Janneke Voltman - SBB

- Marianne Zoetmulder - UWV

- Patrick Leushuis - Ministerie OCW

- Jan Dirk Vlasblom - SCP

- Brigid Claassen - Ministerie van SZW

\section{Tafel 3: Beleidsvragen}

- Een individuele leerrekening of scholingsvoucher geeft mensen middelen en rechten om te investeren in hun eigen inzetbaarheid. Onder welke voorwaarden zou een Individuele leerrekening of scholings-voucher de scholingsdeelname van kwetsbare groepen kunnen bevorderen? En wat heeft de voorkeur?

- Een leerrijke werkomgeving kan een belangrijke rol spelen bij de ontwikkeling en duurzame inzetbaarheid van de werkzame bevolking. Welke stappen zouden werkgevers moeten zetten om zo'n leerrijke werkomgeving te creëren? En hoe zou hetgeen iemand op het werk heeft geleerd zichtbaar gemaakt kunnen worden voor andere werkgevers?

\section{Deelnemers}

- Andries de Grip (voorzitter) - ROA/UM

- Isabel Coenen - FNV

- Remko Hesse - ING

- Adriana Stel - STOOF

- Melanie Lancel - Stichting A+O Metalektro

- Gertrud van Erp - VNONCW-MKB

- Fons Dingelstad - Ministerie van OCW

- Yvonne Bernardt - SER 


\section{Tafel 4: Beleidsvragen}

- $\mathrm{MBO}, \mathrm{HBO}$ en WO instellingen zouden een beter alumnibeleid moeten gaan voeren waarin er aandacht is voor het op up-to-date houden en de verdere ontwikkeling van de competenties en opleidingsbehoefte van afgestudeerden.

Welke stappen zouden onderwijsinstellingen moeten zetten om zo'n leerrijke werkomgeving te creëren?

- Pas-afgestudeerden blijken in tijden van recessie minder vaak cursussen te volgen, terwijl dat belangrijk is voor het hebben van een baan op middellange termijn. Wat zou de overheid kunnen doen om bedrijven te stimuleren om in economisch zware tijden ervoor te zorgen dat hun jonge medewerkers zich voldoende blijven scholen?

\section{Deelnemers}

- Barbara Belfi (voorzitter) - ROA/UM

- Monique Turkenburg - SCP

- Pia Deveneijns - MBO-Raad

- Pia Hindriks - NRO

- Denise van Etten - UWV

- Camiel Jansen - Ministerie SZW

- Jules Sanders - LTO Nederland

- Gerard van Santen - CNV

- Naomi Keuning - Ministerie EZK

- Sander Baljé - Ministerie OCW

\section{Tafel 5: Beleidsvragen}

- Mensen kunnen vaak meer dan wat op dit moment op het werk van ze gevraagd wordt. Hoe kan het werk of de doorstroom op het werk anders georganiseerd worden zodat het onbenut potentieel onder werkenden beter benut wordt?

- Mensen leren vooral door te doen. Dit informeel leren is volgens veel werkenden ook de beste manier om de taakeffectiviteit te vergroten. Welke voorwaarden moeten werkgevers en werknemers scheppen om informeel leren mogelijk te maken en zo vraag en aanbod binnen de huidige baan goed op elkaar te laten aansluiten?

\section{Deelnemers}

- Didier Fouarge (voorzitter) - ROA/UM

- Amerik Klapwijk - VCP

- Gerald Ahn - UWV

- Merel de Groot - Ministerie BZK 
- Jelle Kaldewaij - NRO

- Lotte Tims - (Ministerie OCW)

- Gert-Jan Buitendijk - (Ministerie SZW)

\section{Tafel 6: Beleidsvragen}

- Analytische vaardigheden winnen aan belang op de arbeidsmarkt en de beloning voor deze werktaken stijgt naarmate ze belangrijker zijn voor het uitvoeren van het werk. Toch is er ook sprake van onderkwalificatie. Welke rol moeten overheid en sociale partners in gerichte investeringen in dergelijke vaardigheden?

- De complexiteit van het werk neemt toe met het opleidingsniveau, wat betekent dat hoger opgeleiden meer taken gelijktijdig vervullen die van relatief groot belang zijn voor het effectief uitvoeren van hun werk dan lager opgeleiden. Dit stuwt hun waarde ten opzichte van de oudere en lagere opgeleide werknemers. Welk beleid is effectief om deze kloof niet te groot te laten worden?

\section{Deelnemers}

- Bas ter Weel (voorzitter) - SEO

- Albert Bosma - (OOM)

- Marsha Wagner - (Topsector Energie)

- Yvonne Post - (Universiteit Groningen)

- Elize de Bar - (LLO UWV)

- Debby Jutte - (EVC Vigor) 